Universidad de Lima

Escuela de Posgrado

Maestría en Tributación y Política Fiscal

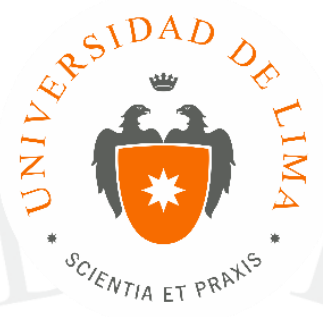

\title{
LA DEDUCCIÓN DE GASTOS PARA LA DETERMINACIÓN DE LA RENTA NETA DEL TRABAJO; UNA APROXIMACIÓN A LA CAPACIDAD CONTRIBUTIVA DE LAS PERSONAS NATURALES
}

TRABAJO DE INVESTIGACIÓN PARA OPTAR EL GRADO ACADÉMICO DE MAESTRO EN TRIBUTACIÓN Y POLÍTICA FISCAL

\section{Daniel Málaga Cuadros \\ Código 20122431

\author{
Asesor \\ César Gamba Valega
}

Lima - Perú

Marzo de 2016 


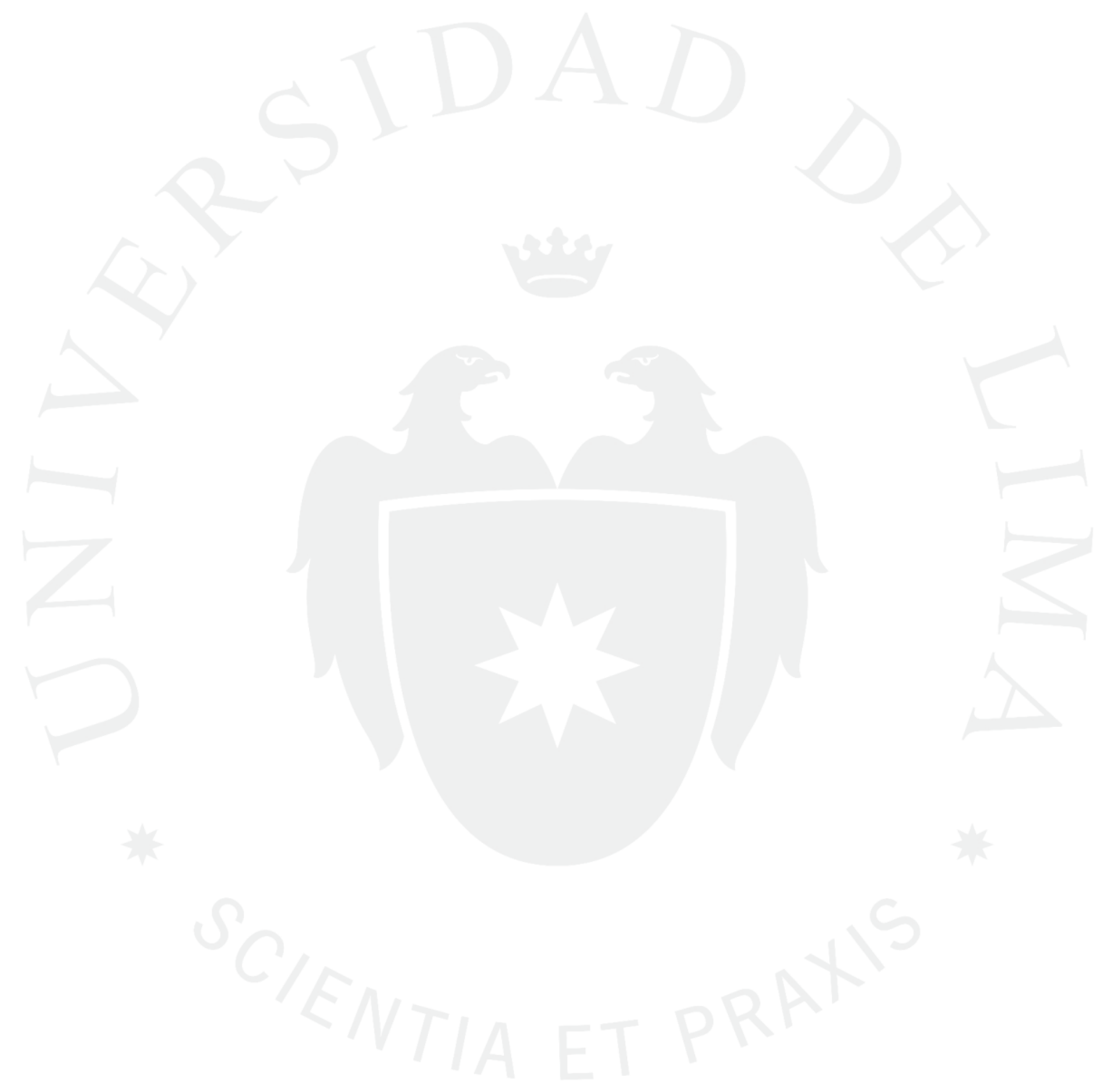


A mis adorados Rodrigo y Cristina, por su amor y comprensión, y a mis padres, modelos de éxito y perseverancia. 


\section{LA DEDUCCIÓN DE GASTOS PARA LA}

DETERMINACIÓN DE LA RENTA NETA DEL TRABAJO; UNA APROXIMACIÓN A LA CAPACIDAD CONTRIBUTIVA DE LAS PERSONAS NATURALES 


\section{TABLA DE CONTENIDOS}

INTRODUCCIÓN

CAPÍTULO I: LA CAPACIDAD CONTRIBUTIVA DE LAS PERSONAS

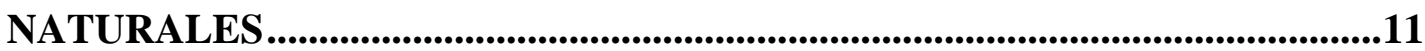

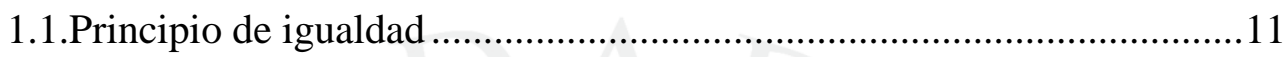

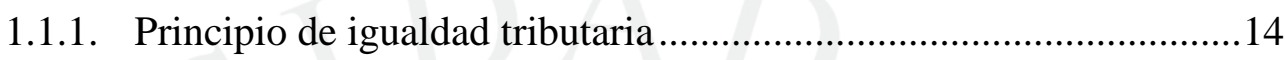

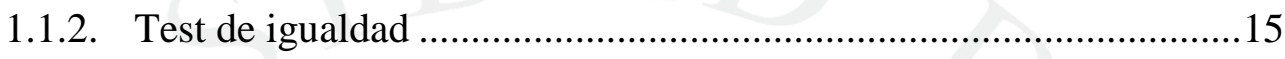

1.1.2.1. Conceptos relevantes en el "Test de Igualdad" ...............................16

1.1.2.2. Aplicación del "Test de Igualdad”................................................17

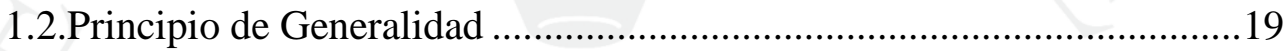

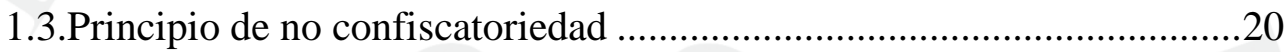

1.4.Diferencia entre el principio de capacidad económica y capacidad

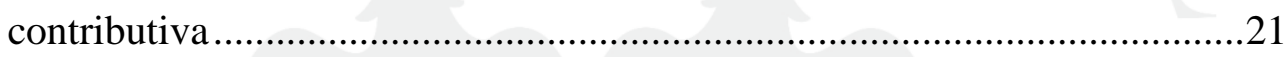

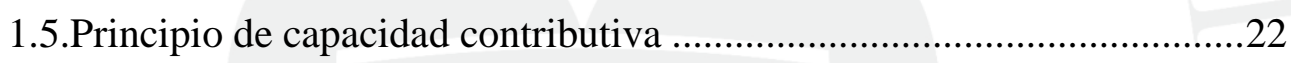

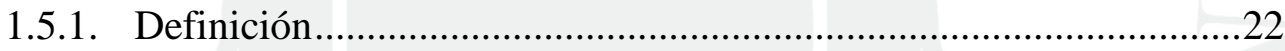

1.5.2.Tipos, elementos, características e índices de capacidad contributiva 24

1.5.3. El "mínimo no imponible” como elemento básico del principio de

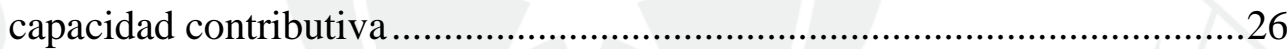

1.5.4. El principio de capacidad contributiva en la jurisprudencia del Tribunal

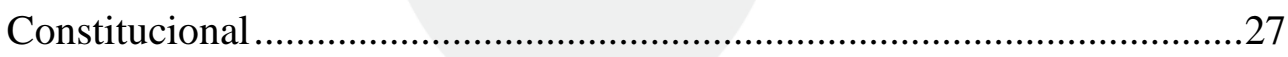

1.5.5. Capacidad Contributiva vs Deber de Contribuir .............................29

1.6.Principio de Practicabilidad en los "Regímenes Simplificados",..........29

\section{CAPÍTULO II: MARCO NORMATIVO DE LAS RENTAS DEL TRABAJO32}

2.1. Antecedentes

2.2. Régimen aplicable a las rentas del trabajo desde 1981 a 1994 (Decreto

Legislativo $\mathrm{N}^{\circ} 200$ )

2.2.1. Conceptos considerados rentas de cuarta categoría. ........................33

2.2.2. Conceptos considerados rentas de quinta categoría.........................33

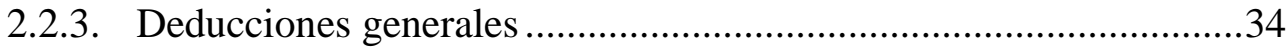

2.2.4. Deducciones especiales admitidas. .................................................34

2.2.4.1. Deducciones de la renta del trabajo independiente. ......................35 
2.2.4.2. Deducciones de la renta del trabajo en relación de dependencia. 36

2.2.5. Deducciones por cargas de familia. .37

2.2.6. Arrastre de pérdidas .37

2.3.Régimen aplicable a las rentas del trabajo desde 1994 hasta la actualidad (Decreto Legislativo $\mathrm{N}^{\circ} 774$ y modificatorias). ..........................................38

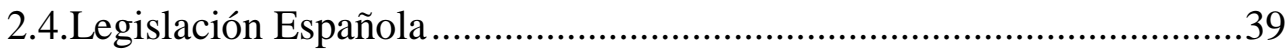

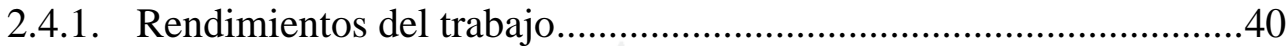

2.4.2. Deducciones a los rendimientos del trabajo...................................40

2.4.2.1. Deducciones aplicables a rendimientos de carácter irregular..........40

2.4.2.2. Deducciones generales .............................................................41

2.4.2.3. Deducciones especiales ........................................................41

2.4.3. Rendimientos de actividades económicas ........................................42

2.4.4. Deducciones de los rendimientos de actividades económicas .........42

2.4.5. Deducciones de la base liquidable general .....................................43

2.4.6. Deducción del mínimo personal y familiar .....................................43

\section{CAPÍTULO III: LAS DEDUCCIONES PARA LA DETERMINACIÓN DE LA} RENTA NETA DEL TRABAJO EN LA LEY DEL IMPUESTO A LA RENTA

3.1. Deducciones para la determinación de la renta neta del trabajo. .45

3.2.Análisis de las deducciones para la determinación de la renta neta del trabajo a través del principio de igualdad ..................................................46

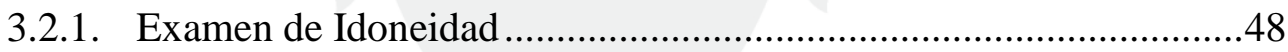

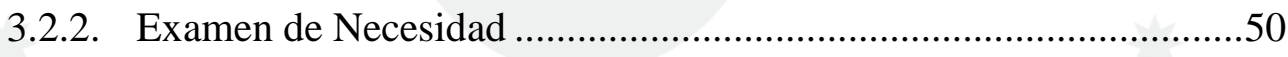

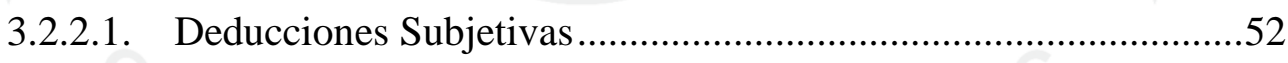

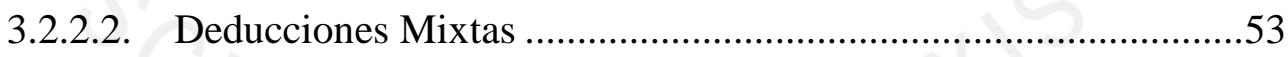

3.2.3. Examen de Proporcionalidad y Razonabilidad ..............................54

3.3.Análisis de las deducciones para la determinación de la renta neta del trabajo a través del principio de no confiscatoriedad

3.4.Análisis de las deducciones para la determinación de la renta neta del trabajo a través del principio de capacidad contributiva .58 3.5. El principio de practicabilidad en las deducciones para la determinación de la renta neta del trabajo. .59

3.6. Alcances para la determinación de la renta neta del trabajo en el Perú.60

3.6.1. Situación económica laboral en el Perú .61 
3.6.2. Deducciones Mixtas; una aproximación a la capacidad contributiva de las personas naturales generadoras de rentas del trabajo. 63

3.6.2.1. Deducciones básicas .................................................................66

3.6.2.2. Deducciones para la determinación de la renta neta del trabajo dependiente .71

3.6.2.3. Deducciones para la determinación de la renta neta del trabajo independiente .73

CONCLUSIONES . .77 


\section{INTRODUCCIÓN}

Anualmente gran parte de las personas que laboran de manera independiente y/o dependiente presentan su declaración jurada anual del Impuesto a la Renta y pagan el impuesto resultante, sin embargo, cuántas veces nos hemos preguntado si el impuesto que pagan por la renta percibida corresponde al gravamen que deben soportar. En ese sentido, el presente trabajo trata de dilucidar si nuestra legislación del Impuesto a la Renta responde satisfactoriamente al principio de capacidad contributiva en el caso de las rentas del trabajo, toda vez que es a partir de la capacidad contributiva que podremos concluir si el Impuesto a la Renta que pagan las personas naturales por sus rentas del trabajo se encuentra arreglado a Derecho.

Actualmente existen dos deducciones objetivas para la determinación de la renta neta del trabajo, tanto la generada por el trabajo dependiente como la obtenida por el trabajo independiente, y si bien recientemente se han modificado las tasas progresivas acumulativas para la determinación del Impuesto a la Renta de personas naturales, aumentando escalas en los primeros tramos de ingresos, tal como lo veremos en el presente trabajo, consideramos que ello sólo constituye una mejora superficial, toda vez que no ataca el origen del problema, la base imponible a la que se aplican las alícuotas identificadas en la Ley del Impuesto a la Renta.

En ese sentido, resulta válido cuestionarse si las deducciones objetivas podrían resultar violatorias del principio de capacidad contributiva, habida cuenta que no reparan en la realidad económica de cada persona, esto es, no asumen la aptitud que cada persona tiene para contribuir a través del Impuesto a la Renta con el gasto público como un elemento determinante para atribuirle una carga impositiva.

Lo expuesto se evidenciará con mayor claridad a través de un ejemplo. Supongamos que dos personas que perciben únicamente rentas por su trabajo dependiente, tienen la misma remuneración; de acuerdo con nuestra legislación del Impuesto a la Renta, ambas podrán deducir siete Unidades Impositivas Tributarias UIT de su renta bruta, y al resultado de ello (renta neta) aplicarán las tasas progresivas acumulativas que correspondan; hasta este punto no parece haber problemas, sin embargo, si añadimos al caso propuesto que una de las personas tiene carga familiar, 
ello incidirá directamente en la capacidad contributiva de esa persona, que a pesar que necesita disponer de mayor cantidad de sus ingresos para cubrir sus gastos familiares, no lo puede hacer porque la carga impositiva propuesta por el Estado, no discrimina a los contribuyentes en función a su capacidad contributiva.

Lo expuesto pone en discusión si las deducciones existentes actualmente para la determinación de la renta neta del trabajo, constituyen una vulneración del principio de capacidad contributiva, y si existe la necesidad de implementar un sistema que permita hacer una "discriminación positiva" entre las personas generadoras de rentas del trabajo, en concordancia con el resultado de la diferencia entre las rentas obtenidas y los gastos básicos para su subsistencia y la generación de sus rentas del trabajo; así, a lo largo del presente trabajo se analizará cómo responden las deducciones objetivas para la determinación de la renta neta del trabajo que contempla nuestra Ley del Impuesto a la Renta frente a los principios de igualdad, no confiscatoriedad y capacidad contributiva, así como al principio de practicabilidad. Asimismo, en base al análisis propuesto de las deducciones para la determinación de la renta neta del trabajo, procederemos a ensayar algunos lineamientos y criterios que coadyuvaran a elaborar un sistema de deducciones acorde con los principios tributarios, en especial del principio de capacidad contributiva, esto sin ánimo de establecer fórmulas rígidas o métodos concluyentes, toda vez que ello acarrearía estudios económicos y estadísticos que escapan al objetivo del presente trabajo. 


\section{CAPÍTULO I: LA CAPACIDAD CONTRIBUTIVA DE LAS PERSONAS NATURALES}

Como señalamos en la introducción de este trabajo, antes de abordar el tema propuesto, es necesario a manera de marco teórico, precisar algunos principios tributarios elementales, que como se verá en el punto 1.5 del presente capítulo, constituyen la base del principio de capacidad contributiva, el cual resulta determinante al momento de evaluar la carga impositiva que las personas naturales deben soportar por sus rentas del trabajo.

\subsection{Principio de igualdad}

Según Landa Arroyo et al. (2006), el artículo 2 de la Constitución Política de 1993 que desarrolla el principio de igualdad, debe ser entendido como el derecho de las personas a ser tratadas de la misma manera que quienes se encuentran en su misma situación; de esta concepción, se tiene que el principio de igualdad se opone a la discriminación frente a situaciones que pueden considerarse iguales, sin embargo, ello no implica que no puedan haber situaciones en las que la ley establezca un trato desigual. (p. 256)

Al respecto, el Tribunal Constitucional español (1989, 1990 y 2004) ha señalado en diversa jurisprudencia, que para que pueda emitirse el juicio de igualdad, es necesario que los términos de comparación sean homogéneos, que si existe alguna desigualdad o discriminación ésta se encuentre objetivamente justificada, y que sea razonable, esto es, que ese distinto trato se encuentre dentro de los límites de la proporcionalidad, evitando resultados gravosos o desmedidos.

Similar concepción del principio de igualdad ha sido acuñada por el jurista Álvarez Conde (2003), quien refiere que en virtud de dicho principio no toda discriminación en el ejercicio de los derechos fundamentales de las personas está proscrita, sino que se debe evaluar la razonabilidad y objetividad de tal discriminación para concluir si afecta o no el principio de igualdad. (pp. 324-325) 
Ahora bien, resulta necesario tener en cuenta que los orígenes del principio de igualdad se sustentan en primer término en una dimensión política, y jurídica después a raíz de la Revolución Francesa, lo que explica la dosis de rigidez y formalismo que en un inicio revestía dicho principio, no obstante creemos que este no es el único motivo de ello, sino que persiste una circunstancia adicional, como es que se haya desarrollado dentro de un Estado cuyo rol liberal favoreció a que el objetivo primordial de éste sea afirmar la igualdad de todos los ciudadanos al tributo sin excepciones ante la ley, sin sentir la necesidad de corregir mediante acciones políticas diferenciadas las situaciones de desigualdad efectivas entre los ciudadanos.

No obstante, el principio de igualdad ha ido desarrollándose en el tiempo, habida cuenta que los Estados no se conformaron con haber alcanzado la igualdad ante la ley, es decir, la igualdad que permitía que todos los ciudadanos tuvieran los mismos derechos y garantías, lo cual se reflejaba en la eliminación de las barreras y discriminaciones propias del sistema jurídico y político de ese momento, sino que optaron por llevar el principio de igualdad entre los hombres, es decir, la igualdad de hecho, dándole un carácter instrumental al referido principio para la consecución de los fines supremos que identifican a cada Estado, tales como el libre desenvolvimiento de la personalidad humana y la efectiva participación de los ciudadanos en la organización política y social del país; sin embargo, ello no significa que la igualdad de hecho o igualdad entre los hombres pueda ser tomada como una igualdad matemática que termine por englobar a todos los ciudadanos como si tuvieran los mismos medios y necesidades, toda vez que tal circunstancia conllevaría a una contradicción, al quitársele a los ciudadanos la libertad de tener iniciativa privada, propiedades, derecho a la herencia, entre otros, que evidencian desigualdades económicas, las cuales son perfectamente admitidas por el principio de igualdad, tal como lo ha aceptado el jurista Álvarez Conde, antes citado.

En relación con las desigualdades que admite el principio de igualdad, es justo precisar que éstas no guardan relación con los supuestos de discriminación que en buena cuenta son situaciones en las que la persona se ve inmersa pese a su voluntad, y de las cuales no puede salir por sí sola, no permitiéndosele de esta manera acceder a aquellos bienes y valores que como derechos mínimos le reconoce la constitución.

Justamente, la introducción de desigualdades por parte de los Estados, tiene como objetivo combatir estas discriminaciones, toda vez que no siempre serán 
aplicables medidas iguales para todos los ciudadanos, sobre todo cuando tal circunstancia encierra una potencial afectación, al no haberse tenido en cuenta las condiciones especiales de cada grupo de ciudadanos.

Ahora bien, los criterios sobre igualdad ante la ley, son los siguientes:

a) El principio de igualdad exige que a iguales supuestos de hecho se apliquen iguales consecuencias jurídicas. Serán iguales dos supuestos de hecho cuando la utilización o introducción de elementos diferenciadores sea arbitraria o carezca de fundamento racional.

b) El principio de igualdad no prohíbe al legislador cualquier desigualdad de trato, sino sólo aquellas desigualdades que resulten artificiosas o injustificadas, por no venir fundadas en criterios objetivos y suficientemente razonables de acuerdo con criterios o juicios de valor generalmente aceptados.

c) No toda desigualdad de trato en la Ley supone una infracción del art. 14 de la Constitución, sino que dicha infracción la produce sólo aquella desigualdad que introduce una diferencia entre situaciones que pueden considerarse iguales y que carece de una justificación objetiva y razonable.

d) Para que la diferenciación resulte constitucionalmente lícita no basta con que lo sea el fin que con ella se persigue, sino que es indispensable, además, que las consecuencias jurídicas que resulten de tal distinción sean adecuadas y proporcionadas a dicho fin, de manera que la relación entre la medida adoptada, el resultado que se produce y el fin pretendido por el legislador superen un juicio de proporcionalidad en sede constitucional, evitando resultados especialmente gravosos o desmedidos. (Tribunal Constitucional español, 1990)

De lo expuesto, se tiene que el principio de igualdad, tal como lo habíamos adelantado, no ofrece un sentido de la igualdad en un plano dogmático, sino que trata de establecer una igualdad proporcional, en tanto que se sustenta en la comparación de situaciones semejantes, lo que nos ayuda a concluir de manera general acerca de este principio, que sólo puede existir igualdad entre las personas que ostentan la misma situación en un determinado momento, mas no sobre la generalidad de la sociedad que solo en un pasaje utópico de la realidad podría encontrarse en igual situación. 


\subsubsection{Principio de igualdad tributaria}

El principio de igualdad tributaria es una variante del principio de igualdad con base en los tributos, cuya esencia parte de su vinculación con la capacidad contributiva, toda vez que los supuestos de igualdad toman como base dicho concepto, siendo que sin éste no existiría constitucionalmente la obligación de tributar.

Es así que el principio de igualdad en materia tributaria tiene como objetivo principal establecer una medida de obligación tributaria sustentada en la proporcionalidad y progresividad de la capacidad contributiva de cada persona, debiendo dejarse de lado para tal efecto cualquier otra finalidad exógena, tal como la política económica de un Estado, que generalmente encierra intereses sectoriales contrarios a una justa distribución de las cargas fiscales.

En relación a lo anterior, es importante destacar que acorde con el mandato constitucional que exige tratar en forma desigual a los desiguales entre sí e igual a los iguales entre sí, el principio de igualdad tributaria lleva dicho precepto al ámbito tributario, al considerar que un elemento que transgrede la igualdad de hecho, también puede ocurrir cuando se estructura una norma de tal forma que produzca en sí misma efectos iguales sobre personas que se encuentran en situaciones desiguales o de discriminación.

De lo expuesto en el punto 1.1, se colige que el principio de igualdad en materia tributaria tiene como situación a comparar, la condición económica de cada persona, de esta manera se tendrá que las personas que ostenten la misma condición económica recibirán el mismo trato, mientras que las que no la tengan merecerán un trato diferenciado, permitiendo de ésta manera al legislador proponer tratos diferenciados o discriminatorios entre las personas en base a su particular situación económica, siempre que dichas medidas sean razonables y se encuentren objetivamente justificadas. En ese sentido, de acuerdo con el principio constitucional comentado, el reparto de la carga tributaria en los tributos directos como el Impuesto a la Renta responde a la capacidad que tienen las personas para afrontar determinado gravamen.

En base a lo señalado, podemos concluir que pretender aplicar el mismo sistema de deducciones para la determinación de la renta neta del trabajo a una persona con carga familiar (cónyuge y/o hijos y/o padres dependientes) y a otra sin carga familiar podría vulnerar el principio de igualdad, toda vez que se estaría aplicando la misma 
consecuencia a personas cuya capacidad económica para afrontar un gravamen es distinta.

Es así que con la evolución del Estado a un régimen ligeramente intervencionista, se desarrolló el principio de igualdad tributario, que abarcó un doble significado o función, la primera es la igualdad de todos los ciudadanos ante la ley, lo que supone la paridad de tratamiento y el sometimiento de todos los ciudadanos al tributo sin excepciones ni discriminaciones de ninguna clase, y la segunda consiste en la igualdad conocida como un criterio de medida o cuantificación de las obligaciones tributarias; siendo que esta doble función del principio de igualdad tributario se explica a través de los principios de generalidad y de capacidad contributiva que desarrollaremos más adelante.

\subsubsection{Test de igualdad}

En atención a lo expuesto en el punto 1.1.1, resulta pertinente cuestionarse cuándo estamos ante una norma que vulnera el principio de igualdad; al respecto, el Tribunal Constitucional ha desarrollado un análisis que trata de responder esa interrogante, denominado "Test de Igualdad".

Si bien el "Test de Igualdad", ha sido desarrollado en diferentes sentencias del Tribunal Constitucional, consideramos que la exposición más didáctica del ente jurisdiccional se encuentra recogida en la sentencia recaída en el Expediente $\mathrm{N}^{\circ} 045$ 2004-PI/TC.

De dicha sentencia, se aprecia que el Tribunal Constitucional parte de identificar el mandato del principio de igualdad antes descrito como la "prohibición de discriminación”, no obstante, seguidamente admite a través de los principios de razonabilidad y proporcionalidad que dicho mandato es susceptible de admitir tratamientos diferenciadores que se basen en una justificación objetiva y razonable que guarde estricta relación con la finalidad y efectos de la medida incorporada en salvaguarda de un fin constitucionalmente valioso, es decir, admite que el Estado a través de las normas legales, intervenga en el mandato del principio de igualdad (prohibición de discriminación) con discriminaciones positivas para preservar, promover o proteger un fin constitucionalmente valioso a través de medidas que 
guarden una relación de razonabilidad y proporcionalidad entre los medios empleados y la finalidad perseguida.

De la relación entre los principios de razonabilidad y proporcionalidad empleados por el Tribunal Constitucional, y su reflejo en los medios empleados y la finalidad perseguida, se desprenden a su vez los exámenes de idoneidad y necesidad del tratamiento diferenciado propuesto por el legislador, así como la aplicación del principio de proporcionalidad en sentido estricto, que en buena cuenta se traduce en la denominada "prohibición de exceso".

En ese sentido, tenemos que para verificar si un tratamiento diferenciado, por ejemplo en el caso de la aplicación de deducciones diferenciadas para la determinación de la renta neta del trabajo, se encuentra justificado, es necesario tener en cuenta lo siguiente: i) La medida discriminatoria impuesta debe tener como objetivo preservar, promover o proteger un fin constitucionalmente relevante, ii) El medio utilizado para introducir la medida discriminatoria debe guardar relación con la finalidad perseguida, y iii) El medio utilizado para introducir la medida discriminatoria debe ser idóneo y de especial necesidad.

\subsubsection{Conceptos relevantes en el "Test de Igualdad"}

Una vez descritos los elementos a tener en cuenta para la aplicación del "Test de Igualdad", resulta adecuado definir algunos conceptos utilizados por el Tribunal Constitucional que servirán para la aplicación efectiva del referido test, tales como la intervención en la igualdad, la finalidad del tratamiento diferenciado, el examen de idoneidad, el examen de necesidad y la proporcionalidad en sentido estricto.

Intervención en la igualdad, consiste en una restricción o limitación de derechos subjetivos orientada a la consecución de un fin del poder público. En tanto supone una relación finalista, la intervención del legislador aparece como opción legislativa, un medio del que aquél se sirve para la obtención de un fin. La intervención en la igualdad consiste en la introducción de un trato diferenciado a los destinatarios de la norma que, en cuanto medio, está orientada a la consecución de un fin y que, prima facie, aparece como contraria a la prohibición de discriminación. (Tribunal Constitucional, 2005)

Con relación a la intervención en la igualdad, cabe precisar que ésta admite distintos grados de intensidad: i) grave, cuando la discriminación se sustenta en alguno de los derechos contenidos en el inciso 2 del artículo $2^{\circ}$ de la Constitución e impide el 
ejercicio o goce de un derecho fundamental, ii) media, cuando la discriminación se sustenta en alguno de los derechos contenidos en el inciso 2 del artículo $2^{\circ}$ de la Constitución e impide el ejercicio o goce de un derecho de rango legal o el de un interés legítimo, y iii) leve, cuando la discriminación se sustenta en motivos distintos a los derechos contenidos en el inciso 2 del artículo $2^{\circ}$ de la Constitución e impide el ejercicio o goce de un derecho de rango legal o el de un interés legítimo.

Estos grados de intensidad de la intervención en la igualdad alcanzaran relevancia en el análisis de necesidad en la comparación entre la intensidad del medio utilizado por el legislador y el medio hipotético, mientras que en el análisis de proporcionalidad en sentido estricto, la intensidad de la intervención en la igualdad se comparara con la optimización del fin constitucional perseguido.

La "finalidad del tratamiento diferente", es la situación jurídica que el legislador pretende conformar para la optimización del derecho, principio o bien jurídico cuya finalidad se pretende.

El "Examen de idoneidad", es el análisis sobre si el tratamiento diferenciado propuesto por el legislador conduce a la consecución de un fin constitucional; asimismo, es preciso indicar que el referido análisis tiene dos partes, la primera se refiere a la idoneidad entre el medio utilizado y el objetivo propuesto, y la segunda el de la relación entre el objetivo y la finalidad de la intervención en la igualdad.

El "Examen de necesidad", es la comparación entre el medio utilizado por el legislador, esto es, la intervención en la igualdad, y los medios hipotéticos que éste pudo haber utilizado, resultando preferible el medio que no interviene en la prohibición de discriminación o el que interviniéndola reviste menor intensidad.

La "Proporcionalidad en sentido estricto", consiste en una comparación entre el grado de realización u optimización del fin constitucional y la intensidad de la intervención en la igualdad, es decir, cuanto mayor es la afectación al principio de igualdad, en igual medida debe ser la satisfacción del fin constitucional perseguido con la medida por el legislador.

\subsubsection{Aplicación del "Test de Igualdad"}

Según el Tribunal Constitucional, la aplicación del "Test de Igualdad", debe ser conforme a lo siguiente: 
Los subprincipios de idoneidad, necesidad y proporcionalidad en sentido estricto o ponderación han de aplicarse sucesivamente. Primero, se ha de examinar la idoneidad de la intervención; si la intervención en la igualdad -el trato diferenciado- no es idónea, entonces, será inconstitucional. Por tanto, como se afirmó, no corresponderá examinarlo bajo el subprincipio de necesidad. Por el contrario, si el trato diferenciado -la intervención- fuera idóneo, se procederá a su examen bajo el subprincipio de necesidad. Si aun en este caso, el trato diferenciado superara el examen bajo este principio, corresponderá someterlo a examen bajo el principio de proporcionalidad en sentido estricto o ponderación. (Tribunal Constitucional, 2005)

De lo expuesto, se tiene que para la aplicación del “Test de Igualdad”, resulta necesario guardar un orden correlativo al momento de emplear los tres exámenes (idoneidad, necesidad y proporcionalidad en sentido estricto), sobre todo, cuando conforme se ha expuesto la aplicación de cada uno de ellos podría excluir la aplicación del otro cuando el primero no es superado.

A partir de lo señalado, se tiene que para verificar si un tratamiento diferenciado es inconstitucional, además de observar - como se ha indicado anteriormente - si: i) La medida discriminatoria impuesta debe tener como objetivo preservar, promover o proteger un fin constitucionalmente relevante, ii) El medio utilizado para introducir la medida discriminatoria debe guardar relación con la finalidad perseguida, y iii) El medio utilizado para introducir la medida discriminatoria debe ser idóneo y de especial necesidad; resulta necesario analizar a partir de dichas premisas: i) el grado de intensidad de la medida de intervención en la igualdad ${ }^{1}$, ii) la idoneidad de la medida empleada, iii) la necesidad de la medida empleada, y iv) la proporcionalidad en sentido estricto de la medida empleada, debiendo ser aplicados estos últimos tres análisis en forma consecutiva, siendo que de no superarse alguno de los citados análisis se podrá concluir la inconstitucionalidad de la medida propuesta por el legislador.

Para nuestro caso, el "Test de Igualdad" esbozado por el Tribunal Constitucional, podría incidir si consideramos la inclusión de un régimen diferenciado de deducciones para la determinación de la renta neta del trabajo que tenga como

\footnotetext{
${ }^{1}$ Conforme se ha desarrollado, los grados de intensidad de la medida empleada, sirven para los exámenes de necesidad y proporcionalidad en sentido estricto, en el primero, sirven para identificar el grado de afectación al principio de igualdad y/o las restricciones de goce o ejercicio de derechos legales o constitucionales de la medida empleada en comparación con una medida hipotética, escogiéndose la menos gravosa, y en el segundo sirven para verificar el grado de optimización del fin constitucional perseguido, alcanzado con la medida utilizada.
} 
principio constitucional a ser protegido la capacidad contributiva y como principio afectado - prima facie - el de igualdad, lo que será analizado en el Capítulo III de este trabajo.

\subsection{Principio de Generalidad}

Según Iglesias Ferrer (2000), el principio de generalidad implica que cualquier persona que tenga capacidad contributiva y cuya situación coincida con un supuesto de hecho tributario, debe quedar sujeto a dicho principio, y en consecuencia contribuir con el gasto público; en síntesis lo que expresa el autor es que nadie debe ser eximido de pagar tributos. (p.273)

Como se ha visto del concepto desarrollado, el aporte de este principio va dirigido a que todos los nacionales o residentes de un país deben tributar sin excepción, no obstante, debe tenerse en cuenta que dicho imperativo general solo puede ser reconocido respecto de quienes tienen la capacidad contributiva para afrontar un gravamen, toda vez que aplicar la generalidad sin distinción, podría traer distorsiones e injusticias, por ejemplo, una persona que no puede cubrir sus necesidades básicas para subsistir, no podría soportar un gravamen que agrave aún más su situación.

En ese sentido, el principio de generalidad, al igual que el principio de igualdad antes desarrollado, mantiene exenciones que resultan necesarias para su efectiva aplicación, tales como la exención del "mínimo vital”- concepto que será desarrollado en detalle más adelante - que en buena cuenta es la ganancia mínima que necesita una persona y/o su familia para subsistir. Dicha exención no corresponde solo al interés político y social del Estado de promover la satisfacción de las necesidades básicas de sus ciudadanos, sino también a un precepto económico que señala que el impuesto no puede disminuir la renta mínima, pues de ser así, se verificaría la transferencia del impuesto sobre otros contribuyentes, propiciando un estándar de vida por debajo del "mínimo vital".

Ahora, es importante destacar que si bien el principio de generalidad admite las exenciones al "mínimo vital" como se ha comentado, excluye sin excepción las leyes tributarias que buscan aplicarse a un caso privativo o específico, cuyo efecto cesará al culminar el caso o situación a la cual ha sido aplicada la ley. 
En ese sentido, consideramos que el principio de generalidad, resulta de gran utilidad para comprender posteriormente cómo es que a pesar que los tributos son imperativos para todos los ciudadanos que incurran en un supuesto de hecho o hipótesis de incidencia determinado, sólo terminaran siendo aplicables a algunos de ellos en base a su capacidad contributiva.

\subsection{Principio de no confiscatoriedad}

Antes de entrar a desarrollar un concepto acerca del principio de no confiscatoriedad, es importante tener en cuenta que es recién con la Constitución de 1979, que el Estado reconoce a dicho principio expresamente en su artículo $139^{\circ}, \sin$ embargo, remitió el mismo a los impuestos, lo cual fue superado por la Constitución de 1993, vigente, que en su artículo $74^{\circ}$ precisó que la confiscatoriedad no solo puede ser invocada en relación a los impuestos, sino también a cualquier tributo.

El principio de no confiscatoriedad implica que las personas con capacidad económica que les permita contribuir con el Estado, no vean afectado su derecho a la propiedad por una imposición excesiva; en palabras de Calvo Ortega (2004), se trata de una “...interdicción de carga fiscal exorbitante o extraordinaria”. (p.61)

Asimismo, Danós (2006) menciona que “...se prohíbe la privación de la propiedad privada mediante la utilización de los instrumentos tributarios que a pesar de tener una configuración técnica correcta, afectan gravemente la esfera patrimonial del contribuyente en casos concretos". (p.141)

Hernández Berenguel (2005), precisa que el principio de no confiscatoriedad tiene una doble identidad, la cuantitativa, que se suscita cuando se extrae de la renta o el patrimonio del contribuyente un monto sustancial, lo cual deberá ser apreciado caso por caso, y la cualitativa, que tiene lugar cuando se viola cualquiera de los principios de la tributación, sin interesar la cuantía. (p.969)

Lo acotado por Hernández Berenguel, nos permite concluir que el principio de no confiscatoriedad mantiene una relación estrecha con el principio de capacidad contributiva, en la medida que cualquier tipo de imposición que se aplique a los contribuyentes debe siempre sustentarse en una manifestación de capacidad contributiva; criterio que es compartido por el Tribunal Constitucional en las Sentencias $\mathrm{N}^{\circ}$ 2727-2002-AA/TC y 33-2004-AI/TC. 
En relación a lo expuesto, tendríamos que las deducciones objetivas para la determinación de la renta neta del trabajo, podrían vulnerar el principio de no confiscatoriedad en algunos casos, teniendo en cuenta que las deducciones contempladas en nuestra actual Ley del Impuesto a la Renta, no aseguran que la aplicación de las tasas impositivas sean calculadas sobre la base de la capacidad contributiva de los contribuyentes, elemento preponderante en la configuración de la violación del principio de no confiscatoriedad.

\subsection{Diferencia entre el principio de capacidad económica y capacidad contributiva}

En este punto debemos señalar que si bien el principio de capacidad económica no tiene relevancia jurídica para el derecho tributario, consideramos pertinente hacer referencia al mismo para poder explicar el principio de capacidad contributiva que desarrollaremos más adelante, toda vez que nuestro Tribunal Constitucional (2004), en su definición de capacidad contributiva, parte de la capacidad económica como un concepto distinto que producto de su conjugación con el tributo, permite arribar a una definición más precisa de capacidad contributiva.

En relación a la definición de capacidad económica, Calvo Ortega (2004) señala que es: “...una situación subjetiva patrimonial en relación con obligaciones dinerarias determinadas.” (p.69) A partir de lo expuesto por Calvo Ortega, se puede señalar que la capacidad económica es la riqueza concreta que posee cada persona en un momento determinado, la cual le permitirá afrontar en primer lugar sus necesidades básicas y en segundo lugar su deber de contribuir con el Estado en el financiamiento del gasto público.

De otro lado, el principio de capacidad económica cumple en nuestro ordenamiento constitucional tributario tres funciones esenciales: de fundamento de la imposición o de la tributación, de límite para el legislador en el desarrollo de su poder tributario y de programa u orientación para el mismo legislador en cuanto al uso de ese poder. (Pérez Royo, 2008, p.58)

En relación a dichas funciones o características, se debe destacar la referida al "límite para el legislador en el desarrollo de su poder tributario", por cuanto dicha función obliga al legislador a mantener una relación directamente proporcional entre la capacidad económica de las personas que se verán afectadas con el tributo y la carga 
impositiva que se pretende imponerles, lo que implica que la inobservancia de ello concluiría con la inconstitucionalidad del tributo.

Lo indicado en el párrafo anterior concuerda con lo expresado por Palao Taboada y Martín Delgado que manifiestan que el principio de capacidad económica obliga al legislador a estructurar un sistema tributario en el que la participación de los ciudadanos en el sostenimiento de los gastos públicos se realice de acuerdo con su capacidad económica, concebida como titularidad de un patrimonio, percepción de una renta o tráfico de bienes. (Como se citó en Martín Queralt, 2008, p.129)

De otro lado, la capacidad contributiva en palabras de Moschetti (2001), es la riqueza que una persona genera $\mathrm{u}$ obtiene, siendo que todo aquello que constituya un empobrecimiento o un desmedro en el patrimonio de la persona, o no tenga relevancia económica, no representará una capacidad contributiva. (p.264)

En tal sentido, resulta evidente que la capacidad económica constituye la ganancia o ingresos brutos de una persona en un período de tiempo determinado, los cuales no constituyen en su totalidad la base para la aplicación de un gravamen, a diferencia de la capacidad contributiva, que es la porción de ingresos que resulta de deducir de los ingresos brutos obtenidos por la persona en un período de tiempo determinado, los gastos mínimos indispensables para su subsistencia, siendo dicha porción de ingresos la base para la aplicación de un gravamen, como es el Impuesto a la Renta por ejemplo.

\subsection{Principio de capacidad contributiva}

El artículo $74^{\circ}$ de la Constitución Política del Perú no regula expresamente el principio de capacidad contributiva, pues no aparece recogido en el texto legal del referido artículo, no obstante ello, su aplicación como parámetro constitucional en la creación de tributos por parte del Estado resulta indiscutible.

\subsubsection{Definición}

El principio de capacidad contributiva, también llamado capacidad de pago, es la aptitud económico-social para contribuir al sostenimiento del Estado; al respecto, García Belsunce (1982), define la capacidad contributiva como la diferencia entre la renta bruta del contribuyente y la suma consistente en las erogaciones indispensables para su consumo más un adecuado porcentaje para su ahorro y capitalización. (p.115) 
Según García López-Guerrero, en virtud del principio de capacidad contributiva, las personas deben contribuir a través de impuestos directos en proporción directa con su capacidad económica, de modo tal que quien tenga mayores ingresos pagara más, y quien tenga menores ingresos pagará menos impuestos directos. (Como se citó en Landa Arroyo, 2006, p.262)

Por su parte Moschetti (2001) sostiene que en el ámbito de un juicio de igualdad, el principio de capacidad contributiva es principio constitucional de justicia fiscal, válido para cada particular. (p. 244)

Ahora bien, a partir de las definiciones esbozadas, podemos concluir que la riqueza de un individuo no solo se manifiesta como un derecho, sino también como un deber de solidaridad para contribuir con los gastos públicos, lo cual a veces y por las imperiosas exigencias de presupuesto público de un lado y de amplias evasiones de otro, termina por inducir al legislador a adoptar medidas desequilibradas a favor del "interés fiscal", tales como atribuir ganancias, rendimientos y retribuciones que no sean probadas, sino fijadas por la autoridad según criterios abstractos y generales.

Al respecto, debemos tener en cuenta que el deber tributario es un deber de solidaridad de todos aquellos que tengan capacidad contributiva y en razón de tal capacidad, por lo que las soluciones legislativas sumarias que para tutelar un interés sacrifican otro, las hacen ilegitimas; en ese sentido, no existe una capacidad contributiva general y abstracta referida a "sujetos-tipo", sino una capacidad contributiva del particular, posición que ha sido refrendada por el Tribunal Constitucional Español (1990) al referir que la recepción constitucional del deber de contribuir al sostenimiento de los gastos públicos según la capacidad económica de cada contribuyente configura un mandato que vincula tanto a los poderes públicos como a los ciudadanos e incide en la naturaleza misma de la relación tributaria.

Asimismo es importante tener en cuenta que:

Nadie puede tener la ilusión de poder alcanzar una igualdad en sentido absoluto en la carga tributaria y esto no solo por la imposibilidad de cuantificar el sacrificio, sino por la imposibilidad técnica de alcanzarla. Es suficiente conformarse con una igualdad relativa, de modo que los sujetos que se encuentren en las mismas condiciones sean puestos bajo un mismo tratamiento fiscal, porque es utópico pensar en una distribución absolutamente justa de los impuestos entre sujetos que se encuentran en idénticas condiciones. (Víctor Uckmar, 2002, p.67) 
De lo señalado, se evidencia que la capacidad contributiva sólo puede exigirse desde el punto de vista relativo y no absoluto, esto es, que se privilegie una imposición proporcional a la capacidad contributiva de cada contribuyente, a fin de no afectar la propia existencia del mismo.

\subsubsection{Tipos, elementos, características e índices de capacidad contributiva}

Es posible identificar dos tipos o clases de capacidad contributiva, la capacidad contributiva absoluta y la capacidad contributiva relativa, la primera es la aptitud abstracta para concurrir a soportar las cargas tributarias, mientras que la segunda se encuentra orientada a la determinación de la carga tributaria, debiendo destacarse que su principal distinción radica en los momentos en que actúa cada una, mientras que la capacidad contributiva absoluta interviene cuando se delimitan los presupuestos de hecho, la capacidad contributiva relativa nace para fijar los elementos de la cuantificación de la deuda tributaria.

Según Spisso (2002), el principio de capacidad contributiva posee dos elementos, uno objetivo que se refiere a la cantidad de riqueza; y, otro subjetivo, que relaciona la riqueza con la persona del contribuyente. En relación a la capacidad contributiva objetiva, considera que se deben cumplir tres requisitos: a) Que el gravamen se aplique a rendimientos netos, esto es, que el gravamen recaiga sobre la riqueza disponible; b) La continuidad del ciclo productivo, esto es, que las exigencias que se imponen para la determinación del tributo no genere una separación entre los diversos períodos impositivos; y c) Que no se sometan a tributación rendimientos ficticios. Asimismo, indica como requisitos de la capacidad contributiva subjetiva, relacionada con el mínimo exento, los siguientes: a) Los niveles de costo de vida; b) El grado de desarrollo o de bienes alcanzados por cada sociedad; y c) El nivel de calidad y cantidad de los servicios prestados por el Estado.

En relación a las características del principio de capacidad contributiva, éstas se pueden resumir en dos: i) revela la posibilidad de las personas de contribuir con el gasto público, y ii) establece límites a la potestad tributaria del Estado. Ambas características se encuentran relacionadas directamente con el principio de capacidad económica, habida cuenta que es en virtud a dicha capacidad que se podrá concluir la aptitud de las personas para afrontar una determinada carga impositiva. (p.361 y 362) 
En relación a la posibilidad de las personas de contribuir con el gasto público, es preciso indicar que ésta se encuentra premunida por el deber de contribuir que tienen los integrantes de una sociedad que realizan hechos económicos que los ponen en aptitud de contribuir para soportar las cargas públicas.

Respecto al principio de capacidad contributiva como límite de la potestad tributaria, resulta lógico imponer al Estado límites a su potestad tributaria, a fin de evitar que éste introduzca elementos ajenos a los principios rectores de la tributación que terminen transgrediendo los mismos. No cabe duda que el Estado puede gravar las manifestaciones de riqueza, como es el caso de la renta neta en el caso del Impuesto a la Renta, sin embargo, podría darse el caso que emplee mecanismos impropios para tal fin que pudieran terminar gravando la renta bruta, lo cual resultaría inconstitucional.

De lo expuesto, se tiene que las dos características básicas del principio de capacidad contributiva actúan como marco para atribuir cargas impositivas a las personas y como parámetro para la formulación del tributo por parte del Estado, lo cual tomaremos en cuenta al momento de establecer si las deducciones objetivas planteadas en nuestra Ley del Impuesto a la Renta han sido diseñadas teniendo en cuenta el principio de capacidad contributiva.

Respecto a los índices de capacidad contributiva de una persona, éstos son indicadores que permiten al Estado conocer la posibilidad de una persona de afrontar un gravamen, los cuales pueden ser directos, como en el caso de propiedades que posee la persona o la percepción de rentas, o indirectos, como puede ser la circulación y el consumo de la riqueza.

Asimismo, a fin de utilizar los índices comentados, cabe tener en cuenta lo siguiente: i) Todo contribuyente que se encuentre apto económicamente y que este subsumido en un supuesto de hecho tributario debe contribuir; ii) el sistema tributario debe estar estructurado de tal manera que quien tenga mayor capacidad económica tenga una mayor participación ante el fisco; iii) no deben seleccionarse supuesto de hecho tributarios, circunstancias o situaciones que no sean idóneas para reflejar capacidad contributiva; y iv) el tributo o tributos que recaigan sobre un contribuyente no pueden exceder su capacidad contributiva, habida cuenta que en dicho caso se estaría ante una confiscación.

Es así que los índices para determinar la capacidad contributiva de cada persona, contribuirán en nuestro análisis, a efectos de establecer la idoneidad de las medidas empleadas por el Estado para medir la capacidad contributiva. 


\subsubsection{El "mínimo no imponible” como elemento básico del principio de capacidad contributiva}

De acuerdo con lo señalado anteriormente, la carga impositiva debe reposar sobre las personas en virtud de su capacidad económica, sin embargo, ello no implica necesariamente que todas las manifestaciones económicas de riqueza que una persona pudiera tener en un determinado momento puedan o deban ser gravadas, toda vez que admitir tal circunstancia conllevaría a sostener que todas las necesidades básicas de las personas están cubiertas por el Estado, lo cual en el Perú así como en la mayoría de países de la región, resulta a todas luces una falacia; en ese sentido se ha considerado como un paradigma de la tributación - sobre todo en el caso de los impuestos directos la introducción del concepto denominado "mínimo no imponible" o "mínimo vital".

Según Calvo Ortega (2008) el mínimo vital debe ser entendido como el conjunto de recursos económicos referidos a una unidad de tiempo que permite atender las necesidades elementales personales y familiares; asimismo, el autor precisa que este mínimo vital es aplicable sólo a las personas físicas. (p. 54 y 55)

De lo anterior, se puede deducir que el mínimo no imponible es la porción de riqueza de la persona que se encuentra dedicada a cubrir sus necesidades básicas y que por tanto no puede ser gravada; éste concepto constituye el elemento básico diferenciador entre capacidad económica y capacidad contributiva. A lo expuesto, Martín Delgado añade que la determinación del mínimo vital constituirá un problema de justicia que dependerá de cuál sea el ideal sentido por la comunidad en cada momento histórico y adoptado por el ordenamiento jurídico. Puede abarcar desde el llamado "mínimo físico" o exención del conjunto de bienes indispensables para mantener la vida del individuo, al "mínimo social", que comprende ya lo que se entiende indispensable para el tenor de vida del individuo, concluyendo que la dimensión de este mínimo de existencia va a depender en concreto de cómo esté configurado el sistema financiero del Estado y de cuáles sean las actividades que se desarrollan por el mismo. Es evidente que en un Estado en que las primeras necesidades de los individuos aparezcan cubiertas por la actividad pública, es decir, por la actuación del sector público, la exención del mínimo de existencia tendrá menos sentido que en aquellos Estados en los que el fundamento liberal de la organización socioeconómica 
deje al libre juego de las economías individuales la cobertura de estas necesidades. (Como se citó en Martin Queralt, 2008, p.128)

En ese sentido, como lo hemos indicado al inicio de éste título, el mínimo no imponible constituye un elemento preponderante del principio de capacidad contributiva, por cuanto en base a dicho concepto se establecerá la porción de riqueza o renta excedente del monto que sirve para cubrir las necesidades básicas de las personas, susceptible de ser gravada, para lo cual deberá tenerse en cuenta entre otros elementos, los detallados en el punto 1.5.2 anterior.

En relación con lo expuesto, podemos concluir por ejemplo, que en el caso de las personas naturales que tributan por sus rentas del trabajo en el país, el mínimo no imponible debería estar constituido por lo menos por las erogaciones dirigidas a satisfacer las necesidades de alimentación básica familiar, vivienda, educación y servicios de salud, toda vez que actualmente éstas no son cubiertas por el Estado de manera satisfactoria ${ }^{2}$, lo cual será analizado con mayor detalle en el Capítulo III del presente trabajo.

\subsubsection{El principio de capacidad contributiva en la jurisprudencia del Tribunal Constitucional}

La no inclusión expresa del principio de capacidad contributiva en nuestra Constitución, ha propiciado que el Tribunal Constitucional se avoque a la tarea de desarrollar dicho principio en el ordenamiento jurídico nacional.

Al respecto, el citado ente colegiado ha abordado el principio de capacidad contributiva a través de la sentencia recaída en el Expediente $\mathrm{N}^{\circ} 0033-2004-\mathrm{AI} / \mathrm{TC}^{3}$ de 28 de setiembre de 2004.

El jurista Tarsitano define el principio de capacidad contributiva como la aptitud del contribuyente para ser sujeto pasivo de obligaciones tributarias, aptitud que viene establecida por la presencia de hechos reveladores de riqueza (capacidad económica)

2 Según Informe Técnico de la Evolución de la Pobreza Monetaria 2007 - 2012. Lima, mayo 2013.

Disponible en:

http://www.inei.gob.pe/media/cifras_de_pobreza/pobreza_informetecnico2013_1.pdf (Consulta realizada el 11 de julio de 2014).

3 Acción de inconstitucionalidad interpuesta por los señores Roberto Nesta Brero y Augusto Javier Aida Susuki, en representación de más de 5,087 ciudadanos con firmas certificadas contra el artículo $125^{\circ}$ del Texto Único Ordenado de la ley del Impuesto a la Renta, aprobado por Decreto Supremo $\mathrm{N}^{\circ}$ 054-99-EF, el que fuera incorporado por el decreto Legislativo $\mathrm{N}^{\circ} 945$, y contra la Quinta Disposición Transitoria y Final de la Ley N²7804. 
que luego de ser sometidos a la valorización del legislador y conciliados con los fines de naturaleza política, social y económica, son elevados al rango de categoría imponible. (Como se cita en Tribunal Constitucional sentencia recaída en el Expediente $\mathrm{N}^{\circ}$ 0033-2004-AI/TC)

El Tribunal Constitucional en la referida sentencia precisa a partir de la definición antes citada, que la capacidad contributiva constituye una categoría distinta a la capacidad económica a cuya determinación solamente se llega luego que la manifestación de riqueza observada por el legislador, siempre de manera objetiva, es evaluada, sopesada y contrapuesta a los diversos fines estatales para considerarla como hecho imponible.

En la sentencia comentada se señala además que:

La capacidad contributiva tiene un nexo indisoluble con el hecho sometido a imposición; es decir, siempre que se establezca un tributo, éste deberá guardar íntima relación con la capacidad económica de los sujetos obligados, ya que sólo así se respetara la aptitud del contribuyente para tributar o, lo que es lo mismo, sólo así el tributo no excederá los límites de la capacidad contributiva del sujeto pasivo, configurándose el presupuesto legitimador en materia tributaria y respetando el criterio de justicia tributaria en el cual se debe inspirar el legislador, procurando siempre el equilibrio entre el bienestar general y el marco constitucional tributario al momento de regular cada figura tributaria. De modo que, cuando el Tribunal Constitucional reconoce que todo tributo que establezca el legislador debe sustentarse en una manifestación de capacidad contributiva (STC N ${ }^{\circ}$ 2727-2002-AA/TC), lo que hace es confirmar que la relación entre capacidad económica y tributo constituye el marco que, en términos generales, legitima la existencia de capacidad contributiva como principio tributario implícito dentro del texto constitucional. (Tribunal Constitucional, 2004)

De lo expuesto, se tiene que el Tribunal Constitucional de manera acertada a nuestro criterio, ha desarrollado el principio de capacidad contributiva a partir de un concepto teórico como es el de capacidad económica, el cual si bien no constituye por sí mismo un concepto relevante para el derecho tributario, dicha percepción cambia cuando es analizado en perspectiva al principio de capacidad contributiva.

En ese sentido, el análisis del Tribunal Constitucional para definir el principio de capacidad contributiva, se centra en introducir en el concepto de capacidad económica, un elemento característico de los impuestos directos, como es el "mínimo no imponible”, para que a partir de ello, se identifique con mayor claridad la porción de 
riqueza que una persona en particular tiene para afrontar una carga impositiva, lo que en buena cuenta es la capacidad contributiva de ésta.

\subsubsection{Capacidad Contributiva vs Deber de Contribuir}

Muchas veces, se ha visto planteada a manera de posiciones encontradas, la racionalidad del principio de capacidad contributiva con el deber de todos los ciudadanos de contribuir con el gasto público, ello básicamente en nuestro caso, con motivo de las Sentencias del Tribunal Constitucional recaídas en los Expedientes $\mathrm{N}^{\circ}$ 0004-2004-AI/TC, 00053-2004-PI/TC, 03797-2006-PA/TC у 06089-2006-PA/TC.

En dichas sentencias, nuestro Tribunal Constitucional, estableció que es deber de todos los ciudadanos contribuir a los gastos públicos, esto como una manifestación del principio de solidaridad o también llamada por Bravo Cucci (2013), como la "teoría solidarística del deber de contribuir", esta teoría esbozada por el Tribunal Constitucional, se sustenta en el Estado Social de Derecho, a partir del cual, el Tribunal considera que el principio de solidaridad puede justificar la violación de cualquiera de los principios tributarios de capacidad contributiva, igualdad, no confiscatoriedad e incluso respeto a los derechos fundamentales, es decir, se utiliza el principio de solidaridad como fundamento de un tributo, lo cual a todas luces resulta sesgado.

Efectivamente, el Estado Social no habilita al Estado a dejar de servir los intereses de los particulares para exacerbar los intereses generales, siendo además que utilizar la solidaridad como fundamento del tributo, va contra la naturaleza jurídica de dicho principio, el cual constituye la justificación del deber de contribuir, mas no una expresión de la justicia tributaria ni un principio jurídico que limite o module la potestad tributaria. (p.33)

En ese sentido, tenemos que el deber de contribuir fundado en el principio de solidaridad, no constituye una contraposición al principio de capacidad contributiva, sino que el deber de contribuir debe ser promovido por el Estado en función a la capacidad de contributiva de cada ciudadano, y nunca en menoscabo de los principios tributarios que rigen la creación de los tributos.

\subsection{Principio de Practicabilidad en los "Regímenes Simplificados"}

El principio de practicabilidad, forma parte de la técnica de legislación, que en Alemania se denomina ciencia de la legislación, y que tiene su origen en la 
jurisprudencia y doctrina alemana, como resultado de entender que existe una desproporción entre los deberes que impone la ley al Estado, y la capacidad que éste tiene para llevar a cabo dichos deberes.

Según Arndt, el principio de practicabilidad es el conjunto de medios y técnicas utilizables con el objetivo de hacer simple y viable la ejecución de las leyes, mientras que Costa, señala que la practicabilidad es el conjunto de técnicas encaminadas a alcanzar la adecuada ejecución del ordenamiento jurídico, estando presente en toda la actuación estatal, tanto en el ejercicio de la función legislativa, como en el ejercicio de las funciones de aplicación de la ley. (Como se cita en Rodríguez Losada, 2011, p.439)

En función a lo señalado, tenemos que el principio de practicabilidad, persigue que las normas, tributarias por ejemplo, sean aplicables por el Estado y practicables por los contribuyentes, lo que puede ser traducido en la simplificación del tributo, de su cuantificación y de los métodos de pago, que en buena cuenta forman parte del denominado "Régimen Simplificado”, comúnmente aplicado en la mayoría de países de Latinoamérica, y cuya característica principal es la introducción de abstracciones conceptuales, tales como presunciones, ficciones, enumeraciones taxativas, compendios y cuantificaciones, en situaciones que sean susceptibles de aplicación a una generalidad de contribuyentes.

Si bien como hemos señalado anteriormente, la manifestación del principio de practicabilidad se da a través de presunciones, ficciones, conceptos jurídicos indeterminados, entre otras posibilidades, siendo el tema central del presente trabajo el análisis de las deducciones objetivas para la determinación de la renta neta del trabajo, resulta de principal relevancia desarrollar las denominadas "normas de simplificación" en la doctrina alemana.

Las "normas de simplificación" nacen como una alternativa a la cuantificación del hecho imponible de manera directa, en respuesta a la necesidad de los contribuyentes de simplificar y flexibilizar sus obligaciones formales tributarias; sin embargo, para Herrera Molina (1998), estas normas de simplificación no hacen más simple el sistema tributario, sino que a través de ellas se renuncia a gravar la manifestación de capacidad económica que constituye el objeto de un determinado tributo. (p.164)

En ese sentido, surge la interrogante acerca de si se debe preferir las normas de simplificación y sacrificar en parte el principio de capacidad contributiva, o si se debe privilegiar éste último principio por sobre los caracteres típicos o incidiarios de dichas 
“normas de simplificación”, que denuncia Herrera Molina (1998), las cuales son: la seguridad jurídica para los contribuyentes, la imposibilidad que las normas tributarias recojan situaciones concretas y la practicabilidad administrativa. (p.164)

$\mathrm{Al}$ respecto, cabe indicar que existen pronunciamientos favorables, en los que se acota que para evitar la complejidad del procedimiento tributario que podría requerir la aplicación consecuente de la categoría legal de rendimiento neto, así como la dificultad de comprobar la existencia y cuantía de ciertos gastos, con excesivos costes de gestión, el legislador puede recurrir a una técnica en la que no se exija una cuantificación exacta de los gastos producidos y, en su lugar, opere una deducción global o deducciones a tanto alzado, con ciertas deducciones complementarias. Técnica que puede ser apropiada en el ordenamiento tributario por regular actos y relaciones en masa con participación de los ciudadanos en la gestión y aplicación de los tributos y, de otra parte, en la medida en que es susceptible de evitar eventuales actuaciones fraudulentas y satisfacer la exigencia de seguridad jurídica. (Tribunal Constitucional español, 1994)

Ahora, el Tribunal Constitucional español, no agota su análisis en la aplicación de las normas de simplificación y su relación con el principio de capacidad económica, sino que advierte que resulta necesario someter dichas medidas adicionalmente a los principios de generalidad, igualdad y seguridad jurídica en cada caso, a fin de verificar el grado de eficiencia de las "normas de simplificación" que se pretenden utilizar, lo cual se puede medir en función a la aplicación efectiva del sistema tributario sobre la generalidad de los contribuyentes.

De lo anotado, se tiene que las deducciones objetivas establecidas en la Ley del Impuesto a la Renta para la determinación de la renta neta del trabajo, no son per sé contrarias al ordenamiento constitucional, en especial al principio de capacidad contributiva, sino que constituyen "normas de simplificación" que fomentan la practicabilidad administrativa, la simplicidad del sistema tributario y la eficiencia del Impuesto a la Renta, sin embargo, la enunciada conclusión preliminar no debe dejar de lado el análisis sobre la eficacia de las deducciones objetivas en nuestro ordenamiento jurídico tributario, en relación a los principios de igualdad, capacidad contributiva y seguridad jurídica, lo cual será abordado en el Capítulo III del presente trabajo. 


\section{CAPÍTULO II: MARCO NORMATIVO DE LAS RENTAS DEL TRABAJO}

\subsection{Antecedentes}

A inicios de 1930 el Estado peruano se vio en la necesidad de implementar una reforma tributaria que le permita aumentar su recaudación, toda vez que el crecimiento constante de la población y de sus necesidades básicas durante la última década, requerían una mayor inversión por parte del Estado, lo que se tradujo en el crecimiento constante del gasto público.

En ese contexto se creó la Ley $\mathrm{N}^{\circ} 7904$ de 26 de julio de 1934, la cual implementó un sistema mixto de impuestos cedulares con un impuesto complementario de tasas progresivas sobre la renta global; sin embargo, las sucesivas modificaciones a la referida ley, derivaron en la creación de una comisión revisora de la legislación tributaria en 1962, cuya labor culminó en 1967 con el proyecto denominado "Ley de Tributación Directa" que sentó la base para la creación del Decreto Supremo N ${ }^{\circ} 287$ 68-HC, el cual optó por adherirse al concepto de fuente sin abdicar su facultad de gravar expresamente otros tipos de ingresos.

Posteriormente, a pesar de la prolijidad del Decreto Supremo $N^{\circ}$ 287-68-HC, terminado el gobierno militar, se inició una nueva reforma tributaria respecto del Impuesto a la Renta, la cual culminó con la dación del Decreto Legislativo $\mathrm{N}^{\circ} 200$ en el año 1981; dicha norma conservó la adhesión al concepto de renta según la teoría de la fuente, sin dejar de lado la posibilidad de gravar otros ingresos ocasionales o extraordinarios que pudieran darse, previendo los cambios sociales, económicos y tecnológicos que tuvieron lugar en años posteriores, lo que incidió en que el referido decreto perdurara en su esencia hasta la fecha.

Estando a las consideraciones expuestas, hemos tomado como punto de partida del presente capítulo, el Decreto Legislativo $\mathrm{N}^{\circ} 200$, en especial la regulación referida a la determinación de la renta neta del trabajo, la cual contribuirá a formar una mejor percepción de la evolución de las rentas del trabajo y su tratamiento en la Ley del Impuesto a la Renta hasta la actualidad, lo que reviste especial relevancia en el presente trabajo. 


\subsection{Régimen aplicable a las rentas del trabajo desde 1981 a $1994^{4}$ (Decreto}

\section{Legislativo $\mathbf{N}^{\circ} \mathbf{2 0 0}$ )}

En el referido instrumento legal, se dispuso de manera expresa que constituían rentas gravadas con el Impuesto a la Renta, las derivadas del trabajo, estableciendo por primera vez las categorías de renta en función a la fuente productora de las mismas, otorgándole a las rentas procedentes del trabajo independiente la denominación de rentas de "cuarta categoría", mientras que a las rentas generadas por el trabajo en relación de dependencia, las denomino rentas de "quinta categoría".

\subsubsection{Conceptos considerados rentas de cuarta categoría.}

Según el referido decreto, las rentas consideradas de cuarta categoría comprendían a las obtenidas por el ejercicio individual o en asociación o sociedad civil de cualquier profesión, arte ciencia, oficio o actividades no incluidas expresamente en la tercera categoría $^{5}$, así como las procedentes del desempeño de funciones de director de empresas, síndico, mandatario, gestor de negocios, albacea y actividades similares.

\subsubsection{Conceptos considerados rentas de quinta categoría.}

En las rentas consideradas de quinta categoría estaban las derivadas del trabajo personal prestado en relación de dependencia, incluidos cargos públicos, electivos o no, tales como sueldos, salarios, asignaciones, emolumentos, primas, dietas, gratificaciones, bonificaciones, aguinaldos, comisiones, compensaciones en dinero o en especie, gastos de representación y, en general, toda retribución por servicios personales, pensiones de jubilación, montepío, rentas vitalicias y cualquier otro ingreso que tuviera su origen en el trabajo personal.

Asimismo, el Decreto Legislativo $\mathrm{N}^{\circ} 200$ dispuso dos clases de deducciones para la determinación de la renta neta del trabajo, las cuales hemos clasificado en deducciones generales, deducciones especiales, deducciones por cargas de familia y el

\footnotetext{
${ }^{4}$ En dicho año entró en vigencia el Decreto Legislativo $\mathrm{N}^{\circ} 774$, derogando el Decreto Legislativo $\mathrm{N}^{\circ}$ 200.

${ }^{5}$ En la tercera categoría se incluyeron las rentas procedentes del comercio, la industria y similares.
} 
arrastre de pérdidas, que si bien no constituye propiamente una deducción, incide en la determinación del Impuesto a la Renta.

\subsubsection{Deducciones generales}

Hemos denominado a esta clase de deducciones como generales, por su aplicación indistinta a las rentas de primera, segunda, cuarta y quinta categoría ${ }^{6}$. Esta clase de deducciones tenía como propósito exceptuar de la renta neta de cualquiera de las categorías de renta antes citadas, a los gastos propios de las necesidades básicas de cualquier persona natural, en observancia del principio de capacidad contributiva.

En ese sentido, se estableció originalmente una deducción objetiva de cuatro Unidades Impositivas Tributarias - UIT aplicable sólo a las rentas de cuarta y quinta categoría, y seguidamente deducciones que respondían a las necesidades de salud, educación y vivienda principalmente, tales como las concernientes a las primas por seguro de vida y accidente del contribuyente y su familia, los honorarios por servicios profesionales médicos, odontológicos, obstétricos y gastos de medicamentos y asistencia hospitalaria realizados por el contribuyente en el país o en el exterior, para la atención de su salud, la de su cónyuge, hijos y padres que constituyan cargas de familia, los gastos de matrícula y de pensiones escolares y de estudios superiores del contribuyente, su cónyuge e hijos realizados en el país, entre otros.

\subsubsection{Deducciones especiales admitidas.}

En este punto veremos como las deducciones generales detalladas en el punto 2.2.3 del presente capítulo han sido complementadas con las deducciones que cada categoría de las rentas del trabajo requerían en virtud al tipo de rentas que fueron asimiladas a cada categoría.

De acuerdo con la clasificación introducida por el artículo $21^{\circ}$ de la Ley del Impuesto a la Renta, las categorías de renta a las cuales se les aplicaba la deducción general comentada, son: a) Primera: Renta de Predios. b) Segunda: Renta de otros capitales. c) Tercera: Renta del comercio, la industria y similares. d) Cuarta: Renta del trabajo independiente. e) Quinta: Renta del trabajo en relación de dependencia. 


\subsubsection{Deducciones de la renta del trabajo independiente.}

Para la determinación de la renta neta del trabajo independiente, existían dos procedimientos que por su naturaleza debían aplicarse de manera excluyente uno de otro $^{7}$.

El primer procedimiento permitía a los contribuyentes deducir de la renta bruta el $15 \%$ del total de las rentas de cuarta categoría obtenidas en el ejercicio hasta un máximo de 2 Unidades Impositivas Tributarias - UIT, no obstante ello, éstos se encontraban habilitados además a deducir otros gastos propios del giro de su profesión, arte u oficio, tales como gastos concernientes a la oficina, taller, estudio o consultorio donde desarrollaban su actividad económica, permitiendo incluso la deducción de gastos vinculados con el personal de apoyo contratado, tales como pagos por concepto de sueldos, honorarios, participaciones, gratificaciones, entre otros.

Como se ha podido apreciar, el legislador en el primer procedimiento utilizó las “normas de simplificación", al emplear un porcentaje de la renta bruta generada por el contribuyente con un límite cuantitativo que si bien no reflejaba estrictamente la capacidad contributiva del contribuyente, flexibilizaba la determinación del Impuesto a la Renta y a su vez simplificaba su fiscalización por parte del Estado; asimismo, en compensación con las deducciones objetivas propuestas, incluía deducciones subjetivas que coadyuvaban a acercar la determinación de la renta neta de cuarta categoría a la verdadera capacidad contributiva del contribuyente.

En buena cuenta, en este caso, el legislador optó por un sistema mixto, que si bien en primer término otorgaba a través de una ficción jurídica una deducción básica o inicial de su renta bruta de cuarta categoría, no dejaba de lado la posibilidad que el contribuyente acreditara otras deducciones que incidieran en la generación de renta de cuarta categoría, en tanto éstas se encontraran debidamente sustentadas ${ }^{9}$.

El segundo procedimiento preveía la deducibilidad de los gastos a que se hace referencia en el primer procedimiento antes de su sustitución por el Decreto Legislativo $\mathrm{N}^{\circ} 298$, así como algunos otros no contemplados en el citado primer procedimiento,

Vid. Artículo $42^{\circ}$ de la Ley del Impuesto a la Renta, creada por Decreto Legislativo $\mathrm{N}^{\circ} 200$. Vid. Punto 1.6. Principio de Practicabilidad en los Regímenes Simplificados. Capítulo I.

El primer procedimiento fue sustituido por el artículo $14^{\circ}$ del Decreto Legislativo $\mathrm{N}^{\circ} 298$, publicado en el diario oficial "El Peruano" el 1 de agosto de 1984. En la modificación introducida, se optó por prescindir del elemento subjetivo de las deducciones y se conservó el elemento objetivo únicamente, al establecer que se deducirá de la renta bruta del ejercicio gravable, por concepto de todo gasto, el $20 \%$ de la misma, hasta el límite de 24 UIT. 
tales como los gastos correspondientes a intereses por deudas y gastos originados por constitución, renovación o cancelación de las mismas, siempre que las deudas hayan sido contraídas para producir rentas gravadas de esta categoría o mantener su fuente productora, primas de seguro que cubran riesgos sobre bienes afectados a la actividad gravada, pérdidas extraordinarias sufridas por caso fortuito o fuerza mayor en bienes productores de renta, entre otros supuestos, pero con la particularidad que éstos debían estar acreditados mediante libros y registros.

En relación a este procedimiento, se aprecia que el legislador buscaba mantener un nivel de elementos que permitieran a los contribuyentes acreditar las deducciones que guardaran relación con la generación de sus rentas de cuarta categoría, admitiendo la posibilidad que éstos asimilaran su base imponible a su verdadera capacidad contributiva.

Al respecto, debemos señalar que si bien el efecto deseado por el principio de capacidad contributiva, es justamente la posibilidad de tributar sobre una base imponible que se encuentre constituida exclusivamente por el excedente de su "mínimo no imponible" y en el caso específico de las rentas de cuarta categoría, por el excedente de los gastos necesarios para generar dicha renta; admitir una fórmula de esta clase, importaría la pérdida de eficiencia del Impuesto a la Renta, en tanto que su determinación por parte de los contribuyentes, así como su posibilidad de fiscalización por parte del Estado resultarían en extremo complicadas y hasta perjudiciales a la luz del principio de practicabilidad desarrollado en el primer capítulo del presente trabajo.

\subsubsection{Deducciones de la renta del trabajo en relación de dependencia.}

Para esta clase de renta del trabajo, el legislador optó por un solo procedimiento para realizar la determinación de la renta neta, esto es, la deducción directa de los gastos generados por los contribuyentes, esencialmente, las deducciones referidas a las contribuciones pagadas a entidades nacionales por concepto de seguridad social y los descuentos hechos a los servidores públicos para el fondo de cesantía, jubilación y montepío, los tributos que gravan la renta del trabajo y son de cargo de quien percibe dicha renta, y los tributos y las contribuciones de seguridad social que graven la renta de trabajo y sean de cargo de quien perciba dicha renta.

De lo expuesto, se tiene que el legislador atribuyó a las rentas de quinta categoría, deducciones que corresponden principalmente a erogaciones impuestas 
gastos que no dependen de los contribuyentes, sino que se encuentran impuestos por el legislador; asimismo, cabe resaltar que resulta congruente la no inclusión de otras deducciones en esta categoría, toda vez que resulta evidente que quien labora en relación de dependencia no incurre en mayores gastos respecto al desarrollo de sus labores.

En concordancia con lo señalado en el párrafo anterior, debemos indicar que el nivel mínimo de deducciones previsto para las rentas de quinta categoría en comparación con el establecido para las rentas de cuarta categoría, se explica por cuanto ésta última clase de rentas implica una inversión que no siempre genera los réditos esperados, a diferencia de las rentas de quinta categoría, por las que el contribuyente siempre obtendrá un ingreso, sin mayor inversión que la de su tiempo.

\subsubsection{Deducciones por cargas de familia.}

El artículo $57^{\circ}$ del Decreto Legislativo $\mathrm{N}^{\circ} 200$, sustituido por el artículo $19^{\circ}$ del Decreto Legislativo $\mathrm{N}^{\circ} 298$, introdujo deducciones por cargas familiares, las cuales consistían en 1 UIT anual por cada una de las personas que se encontraran a su cargo, carecieran de renta propia y residieran en el Perú, tales como el cónyuge; hijos menores de 18 años o incapaces cualquiera sea su edad, descendientes en línea recta menores de edad o incapacitados para el trabajo; ascendientes en línea recta, hermanos menores de edad o incapacitados para el trabajo, entre otros.

Al respecto, debemos señalar que resulta poco favorable a la simplicidad que debe conservar la determinación de la renta neta del trabajo, el tratar las deducciones por cargas de familia como una clase de deducciones diferente a las que componen el "mínimo no imponible" o como se le ha denominado en el presente trabajo, deducciones generales, debido a que finalmente las cargas de familia son parte de las necesidades básicas de los contribuyentes.

\subsubsection{Arrastre de pérdidas}

El arrastre de pérdidas, según la legislación comentada es aplicable solamente a las rentas de cuarta categoría, y se determina con ciertas limitaciones.

La pérdida es el resultado negativo después de deducir de la renta bruta de cuarta categoría todos los gastos en que hubiera incurrido el contribuyente para generar dicha renta, incluso los gastos que componen las cargas de familia y el mínimo no 
imponible o deducciones generales; dicho resultado negativo o pérdida del ejercicio, solo podía ser utilizado por contribuyentes generadores de renta de cuarta categoría durante sus tres primeros años del ejercicio de la profesión o cuando dicha pérdida hubiera tenido su origen en caso fortuito o fuerza mayor, debidamente comprobados.

En relación a lo expuesto, consideramos acertado que el legislador aplicara el arrastre de pérdidas sólo a las rentas de cuarta categoría, toda vez que como se ha indicado anteriormente, es en este tipo de renta en el que se suelen incurrir en gastos e inversiones que no siempre reditúan a favor del contribuyente, no obstante, nos resulta injustificado que el arrastre de pérdidas se limite a los tres primeros años, por cuanto bien podría un contribuyente obtener pérdidas en cualquier momento del ejercicio de su profesión.

Como reflexión final respecto al Decreto Legislativo $\mathrm{N}^{\circ} 200$, debemos señalar que las bases de éste modelo son adecuadas para formar un método de determinación que permita a los contribuyentes aproximarse a su verdadera capacidad contributiva, pero requiere algunos ajustes que a su vez permitan simplificar la determinación de la renta neta del trabajo, los cuales expondremos en el siguiente capítulo del presente trabajo.

\subsection{Régimen aplicable a las rentas del trabajo desde 1994 hasta la actualidad} (Decreto Legislativo $\mathrm{N}^{\circ} \mathbf{7 7 4}$ y modificatorias).

De acuerdo con nuestra actual Ley del Impuesto a la Renta (en adelante la Ley), las rentas generadas por el trabajo, son las correspondientes al trabajo independiente y al trabajo en relación de dependencia, las cuales han sido tipificadas como rentas de cuarta y quinta categoría, respectivamente.

Asimismo, se tiene que las rentas de cuarta categoría comprenden principalmente las rentas provenientes del ejercicio individual, de cualquier profesión, arte, ciencia, oficio o actividades no incluidas expresamente en la tercera categoría ${ }^{10}$; mientras que las rentas de quinta categoría se encuentran constituidas por el trabajo personal prestado en relación de dependencia.

Según la Ley, la determinación de la renta neta del trabajo se debe establecer de acuerdo a la categoría de renta obtenida: i) en el caso de las rentas de cuarta categoría,

Se consideran rentas de tercera categoría, las rentas del comercio, la industria y otras expresamente consideradas por la Ley. 
se debe deducir de la renta bruta el $20 \%$ de la misma hasta el límite de 24 Unidades Impositivas Tributarias - UIT, ii) en el caso de la obtención de rentas de cuarta y quinta categoría, se debe deducir de la renta bruta 7 UIT anuales por ambas rentas y por una sola vez.

De lo expuesto, se aprecia que el legislador a partir de 1994, prefirió la aplicación de regímenes simplificados para la determinación de la renta neta del trabajo, y con ello la aplicación del principio de practicabilidad en vez de la aplicación estricta del principio de capacidad contributiva, sin embargo, los porcentajes, límites cuantitativos y deducciones objetivas propuestas hace más de veinte años no siempre son eficientes. Conforme hemos concluido en el Capítulo I del presente trabajo, la introducción de regímenes simplificados o de normas de simplificación, sólo se justifican cuando el resultado de preferir la flexibilización importa la ampliación de la base tributaria y la sencillez en la determinación, declaración y pago para los contribuyentes, debiendo precisarse que ello no implica la inobservancia de principios rectores de la tributación como el de igualdad, capacidad contributiva y no confiscatoriedad.

En ese sentido, analizaremos en el Capítulo III del presente trabajo si las deducciones objetivas planteadas por el legislador responden satisfactoriamente a los principios rectores de la tributación, o si el legislador en su afán de simplificación, ha ido más allá de los parámetros esgrimidos por el principio de practicabilidad, marginando los mencionados principios.

\subsection{Legislación Española}

Hemos considerado como legislación comparada a la establecida por el reino de España, por su amplio desarrollo en relación a la determinación de la renta obtenida por rendimientos del trabajo y por actividades económicas de profesionales, teniendo en cuenta la legislación del referido país hasta mayo de $2014^{11}$.

Según Ley 35/2006, de 28 de noviembre, del Impuesto sobre la Renta de las Personas Físicas y de modificación parcial de las leyes de los Impuestos sobre Sociedades, sobre la Renta de no Residentes y sobre el Patrimonio. Real Decreto Legislativo 4/2004, de 5 de marzo, por el que se aprueba el texto refundido de la Ley del Impuesto sobre Sociedades. Asimismo se consultó a la Agencia Tributaria Española. Manual Práctico de Renta y Patrimonio 2013. Disponible en: http://www.agenciatributaria.es/static files/AEAT/DIT/Contenidos_Publicos/CAT/AYUWEB/Bib lioteca_Virtual/Manuales_practicos/Renta/Manual_renta_patrimonio_2013_es_es.pdf (Consulta realizada el 20 de octubre de 2014). 
La legislación española ha desarrollado de manera minuciosa la determinación de la renta derivada del trabajo y de actividades económicas profesionales, no obstante, para efectos del presente trabajo, desarrollaremos de manera general las pautas establecidas tanto en la Ley del Impuesto a la Renta de las Personas Físicas en lo concerniente a los rendimientos del trabajo, como en la Ley del Impuesto a la Renta sobre Sociedades respecto a las actividades económicas profesionales.

\subsubsection{Rendimientos del trabajo}

Se considera rendimiento del trabajo, a la renta que tiene un nexo con el trabajo o la relación laboral del contribuyente, siendo que el trabajo que da origen al rendimiento debe ser prestado en una relación de dependencia; en ese sentido, se tiene que el rendimiento del trabajo es asimilable a lo que en el Perú denominamos renta de quinta categoría.

Dentro de los rendimientos del trabajo, tenemos a las rentas típicas, tales como sueldos y salarios, así como otros rendimientos que no suelen ser tan comunes en nuestra legislación, tales como dietas y asignaciones para gastos de viajes, prestaciones derivadas de sistemas de previsión social, y becas en general, entre otras, debiendo añadirse que los rendimientos en especie, también son computables en esta categoría de renta.

\subsubsection{Deducciones a los rendimientos del trabajo}

La legislación española acoge como deducciones de los rendimientos del trabajo, a: i) las deducciones aplicables a rendimientos de carácter irregular, ii) deducciones generales, y iii) deducciones especiales.

\subsubsection{Deducciones aplicables a rendimientos de carácter irregular}

Los rendimientos irregulares, son los que han sido generados con carácter ocasional o en una pluralidad de periodos anuales, los cuales gozan por tal característica de una deducción de $40 \%$ con un límite cuantitativo específico y requisitos tasados aplicables a dicha deducción especial, los cuales no detallaremos por no resultar relevantes para el presente trabajo. 
Al respecto, consideramos que si bien el desarrollo en relación a la aplicación del porcentaje de reducción a los rendimientos irregulares del trabajo, constituyen prima facie, una vulneración del principio de igualdad, también es cierto que dicha deducción especial refleja las circunstancias y condiciones especiales en las cuales el contribuyente obtuvo dicha renta, lo cual hace notar la razonabilidad de la medida adoptada por el legislador.

\subsubsection{Deducciones generales}

Las deducciones generales admitidas se encuentran dirigidas a establecer el rendimiento neto del trabajo, el cual es el resultado de deducir del rendimiento del trabajo los gastos que a continuación se detallan: i) las cotizaciones a la Seguridad Social o a mutualidades generales obligatorias de funcionarios. ii) Las detracciones por derechos pasivos. iii) Las cotizaciones a los colegios de huérfanos o entidades similares. iv) Las cuotas satisfechas a sindicatos y colegios profesionales, cuando la colegiación tenga carácter obligatorio. v) Los gastos de defensa jurídica derivados directamente de litigios suscitados en la relación del contribuyente con la persona de la que percibe los rendimientos.

Cabe señalar que los gastos detallados responden a la condición de subordinación, propia de los contribuyentes que generan los rendimientos del trabajo, y que los gastos admitidos son exclusivamente los señalados anteriormente.

\subsubsection{Deducciones especiales}

Una vez determinado el rendimiento neto del contribuyente, el legislador español ha previsto una deducción adicional, la cual hemos denominado deducción especial, porque su aplicación depende de una serie de factores, tales como la cuantía del rendimiento, el volumen de rentas que el contribuyente perciba de otras fuentes, la eventual permanencia en actividad una vez cumplidos los 65 años, entre otras circunstancias.

La particularidad con que han sido desarrolladas estas deducciones especiales, permite evaluar circunstancias personales de los contribuyentes, lo que habilita al Estado a tener una visión más clara de su verdadera capacidad contributiva. 


\subsubsection{Rendimientos de actividades económicas}

Se consideran rendimientos de actividades económicas a los que proceden del trabajo personal y del capital conjuntamente o de uno solo de estos factores, dirigidos a la producción o distribución de bienes o servicios, lo cual se asemeja a la concepción de rentas de cuarta categoría que tenemos en el Perú.

\subsubsection{Deducciones de los rendimientos de actividades económicas}

En relación a las deducciones para su determinación, el legislador español ha conceptualizado ésta clase de rentas como procedentes de una microempresa, permitiendo las deducciones previstas en el Impuesto sobre Sociedades, esto es, en buena cuenta, deducciones relacionadas a la generación de renta gravada y al mantenimiento de la fuente productora de la misma, teniendo en cuenta incluso, los bienes patrimoniales afectos a la actividad, esto es, las ganancias o pérdidas generadas por éstos bienes.

En el ámbito formal, ha centralizado la determinación del rendimiento neto de las actividades económicas en métodos de estimación, los cuales son excluyentes uno de otro. La estimación directa normal, es la que se aplica directamente o con carácter general a los contribuyentes que superen una determinada cantidad de ingresos, y consiste en la deducción de gastos tipificados en la Ley del Impuesto a la Renta sobre Sociedades con determinados matices. La estimación directa simplificada, se aplica a los contribuyentes que obtuvieron en el ejercicio un menor monto al establecido para la estimación directa normal, y consiste en la deducción de gastos tipificados en la Ley del Impuesto a la Renta sobre Sociedades, con la particularidad que en el caso de provisiones deducibles y los gastos de difícil cuantificación se aplica el 5\% sobre el rendimiento neto obtenido, y la amortización del inmovilizado material se practica en forma lineal en base a una tabla preestablecida. La estimación objetiva, es aplicada a los contribuyentes que hubieran obtenido un monto menor en relación a los otros dos métodos, en este caso, solo se otorga al contribuyente un sistema preestablecido con porcentajes de deducciones prefijadas, que solo le permite ingresar datos relacionados a los ingresos obtenidos.

De lo expuesto, se tiene que el sistema tributario español, ha permitido la aplicación de normas de simplificación como una opción para los contribuyentes que no se encuentren en capacidad de justificar o determinar detalladamente sus ingresos por 
actividades económicas, o cuyos ingresos menores hagan innecesaria una determinación más compleja; todo esto, sin restringir la posibilidad que los mismos contribuyentes puedan acceder en distintos momentos a practicar una determinación más precisa que se aproxime a su capacidad contributiva.

\subsubsection{Deducciones de la base liquidable general}

La base general, que puede ser negativa o positiva, según los resultados obtenidos en el ejercicio, se encuentra constituida por las ganancias y pérdidas patrimoniales de las rentas derivadas del rendimiento neto del trabajo y el rendimiento neto de actividades económicas, entre otras, que no deriven de la transmisión de bienes y derechos, siendo que de resultar positivo el saldo, éste será considerado la base imponible, y si resulta negativo, constituirá pérdida compensable para los ejercicios posteriores.

En ese sentido la base liquidable general es el resultado de deducir de la base general o base imponible las deducciones por dependencia y envejecimiento, por pensiones compensatorias y por alimentos, así como por cuotas o aportaciones a partidos políticos.

\subsubsection{Deducción del mínimo personal y familiar}

Una vez obtenida la base liquidable general, procede la deducción del importe mínimo personal y familiar, que está constituido por la suma del mínimo del contribuyente y los mínimos por descendientes, ascendientes y por discapacidad.

En relación al mínimo personal de los descendientes, ascendientes y por discapacidad, cabe indicar que los montos a ser deducidos son importes tasados que son aplicados en función a las características especiales de la situación de cada contribuyente, por ejemplo, para la aplicación del mínimo por descendiente, se establece una escala progresiva según la cantidad de descendientes que el contribuyente tiene.

Finalmente, sobre la base del importe resultante de deducir de la base liquidable general, el mínimo personal y familiar, es que se aplican los gravámenes correspondientes.

De lo señalado, tenemos que la combinación de sistemas objetivos y subjetivos para la determinación de la renta neta del trabajo, es viable y a la vez beneficiosa, siempre que permita a los contribuyentes tener la opción de preferir más de un método, 
en función a sus capacidades para llevar a cabo la determinación de su renta neta, y a sus ingresos.

En ese sentido, queda claro que las medidas de intrusión sobre el principio de igualdad, cuando son aplicadas con sustento razonable y proporcional, pueden coadyuvar a los fines de la capacidad contributiva, así como la introducción de regímenes simplificados y deducciones tasadas pueden influir positivamente en la eficiencia que debe tener el Impuesto a la Renta, lo cual se traduce principalmente en la ampliación de la base tributaria. 


\section{CAPÍTULO III: LAS DEDUCCIONES PARA LA DETERMINACIÓN DE LA RENTA NETA DEL TRABAJO EN LA LEY DEL IMPUESTO A LA RENTA}

Conforme se ha indicado en la introducción del presente trabajo, el objetivo es determinar si las deducciones vigentes para la determinación de la renta neta del trabajo responden satisfactoriamente a los principios rectores de la tributación, y en especial al principio de capacidad contributiva, o si lo transgreden. Para ello resulta pertinente analizar la naturaleza de las deducciones actuales permitidas por la Ley del Impuesto a la Renta.

\subsection{Deducciones para la determinación de la renta neta del trabajo}

De acuerdo con lo señalado en el capítulo anterior, la normativa vigente del Impuesto a la Renta prevé una deducción del $20 \%$ de la renta bruta de cuarta categoría obtenida en el ejercicio hasta el límite de 24 UIT, y una deducción adicional de 7 UIT en caso se obtengan además rentas de quinta categoría, siendo que en caso el contribuyente obtuviera únicamente rentas de quinta categoría, solo le correspondería la deducción de 7 UIT.

Así por ejemplo, si una persona natural genera rentas de cuarta categoría por su trabajo independiente $(\mathrm{S} / .50,000.00)$ y rentas de quinta categoría por su trabajo dependiente (S/.40,000.00) en un año, deberá realizar el siguiente cálculo para hallar la renta neta sobre la cual deberá aplicar la tasa progresiva acumulativa que establece la Ley del Impuesto a la Renta:

Paso 1. $50,000+40,000=90,000$ (Total de rentas del trabajo)

Paso 2. $\quad 90,000-7$ UIT $(26,950)=63,050$

Paso 3. $63,050-20 \%(63,050)=50,440($ Renta Neta $)$ 
$\mathrm{Al}$ respecto, debemos indicar que en la exposición de motivos de la Ley del Impuesto a la Renta, creada por el Decreto Legislativo $\mathrm{N}^{\circ} 774^{12}$, no existe justificación técnica o jurídica que permita determinar el origen o naturaleza de dichas deducciones, es decir, las deducciones antes mencionadas son propiamente consecuencia de una decisión legislativa que no responde a un razonamiento preestablecido a partir del cual se puedan justificar las medidas impuestas.

Sin perjuicio de lo expuesto, debemos señalar que actualmente la norma que establece anualmente la Unidad Impositiva Tributaria - UIT, y que sirve de base para la aplicación de las deducciones para la determinación de la renta neta del trabajo, hace referencia expresa a que el valor de la misma, responde a supuestos macroeconómicos, sin embargo, dichos supuestos macroeconómicos difícilmente pueden ser identificados, es decir, si bien la determinación de la UIT cada año proviene de estudios técnicos económicos, resulta muy complicado poder deducir a partir de dichos estudios, la relación entre el resultado económico anual y el aumento incesante de la UIT.

Ahora bien, teniendo en cuenta lo expuesto, corresponde analizar si de acuerdo con los principios tributarios desarrollados en el Capítulo I del presente trabajo, los cuales sirven de sustento al principio de capacidad contributiva, las deducciones vigentes en nuestra Ley del Impuesto a la Renta para la determinación de la renta neta del trabajo, se encuentran bajo los parámetros de los referidos principios tributarios.

\subsection{Análisis de las deducciones para la determinación de la renta neta del trabajo a través del principio de igualdad}

Antes de analizar las deducciones para la determinación de la renta neta del trabajo, resulta importante destacar algunas ideas y conclusiones que han sido esbozadas a lo largo del presente trabajo, y que sirven de fundamento para abordar el tema propuesto.

El principio de capacidad contributiva se encuentra íntimamente ligado al principio de igualdad, al punto que para Ferreiro Lapatza (2006), la capacidad contributiva más que un tercer principio es una forma de entender la generalidad y la igualdad; en ese respecto, el deber de contribuir con las cargas públicas de todos los ciudadanos, si bien es un deber general que debe reflejarse en cada persona por igual,

12 Partimos del referido decreto legislativo por cuanto es a partir de su dación que se instauró el sistema de deducciones para la determinación de la renta neta de cuarta categoría que tenemos hasta la actualidad. 
no debe entenderse como una imposición general sin distinción alguna, sino que debe ponderarse en cada persona su capacidad económica para soportar la carga del gravamen, situación que corresponde reflejar al principio de capacidad contributiva. (p.323)

Ahora bien, la referida capacidad económica, tal como se ha podido apreciar en el Capítulo I, se diferencia de la capacidad contributiva por cuanto la primera solo es un indicador de riqueza, mientras que la segunda refleja la porción que resulta de restar de su capacidad económica el mínimo que posibilite un nivel de vida digno para el contribuyente y su familia, en ese sentido, es sobre ese excedente que se podrá calificar la capacidad del contribuyente para soportar algún gravamen.

De otra parte, cabe indicar que conforme se ha concluido en el Capítulo I del presente trabajo, el principio de igualdad no solo prevé que se adopte un trato igualitario a las personas que posean igual capacidad contributiva, sino que además postula en contraparte, que corresponde dar un trato diferenciado a las personas que tengan distinta capacidad contributiva, toda vez que admitir aplicar las mismas deducciones para un conjunto de contribuyentes, sin tener en cuenta su verdadera capacidad contributiva, podría terminar por transgredir el principio de igualdad.

En ese sentido, consideramos que las deducciones objetivas empleadas por el Estado para la determinación de la renta neta del trabajo, podrían estar lesionando el principio de igualdad, al ser aplicadas de manera general e irrestricta.

Para analizar las deducciones objetivas de la Ley del Impuesto a la Renta en relación al principio de igualdad, resulta adecuado aplicar el "Test de Igualdad" comentado en el Capítulo I del presente trabajo, el cual si bien fue creado para analizar medidas introducidas por el legislador que constituyen una intervención en el mandato de prohibición de discriminación del principio de igualdad, consideramos que puede perfectamente adecuarse a nuestro caso, en el cual partiremos del supuesto contrario, esto es, determinar si la aplicación de las deducciones objetivas para la determinación de la renta neta del trabajo, sin discriminar a los contribuyentes en función a su capacidad contributiva se encuentra acorde con el principio de igualdad; para ello procederemos a verificar si la aplicación de las deducciones objetivas mencionadas 
cumplen uno a uno los exámenes de idoneidad, necesidad, proporcionalidad y razonabilidad empleados por el Tribunal Constitucional en el "Test de Igualdad"13.

Para otorgar una adecuada claridad al análisis, utilizaremos la siguiente Premisa Base:

Dos personas naturales, "A" y "B", generan exclusivamente rentas de cuarta y quinta categoría, obteniendo por sus labores desempeñadas en el ejercicio 2014 los mismos ingresos por cada una de las categorías de renta.

"A" tiene cargas familiares, gastos de educación, salud, vivienda y otros gastos propios de su actividad profesional como médico en su consultorio privado, además de la labor dependiente que realiza en una clínica privada; mientras que "B" no tiene cargas familiares ni gastos de educación, sino solo gastos de salud y vivienda, siendo que al ser abogado de profesión, se dedica además de su labor dependiente en una empresa privada, a la consultoría que desarrolla desde su domicilio.

\subsubsection{Examen de Idoneidad}

Tal como se ha desarrollado en el Capítulo I, el examen de idoneidad tiene como objetivo establecer si la medida empleada por el Estado cumple con el objetivo propuesto, y la relación entre el objetivo y la finalidad del mismo, lo cual implica verificar si la medida empleada guardaba coherencia con el éxito alcanzado respecto al objetivo perseguido, así como establecer si el mencionado objetivo cumple a su vez con la finalidad contemplada por el Estado.

En nuestro caso específico, procede verificar si la aplicación de deducciones objetivas para la determinación de la renta neta del trabajo constituye una medida que cumple con el objetivo para la cual fue creada, y si dicho objetivo guarda relación con la finalidad perseguida y su legitimidad.

Ahora bien, para absolver las interrogantes planteadas, corresponde en primer lugar identificar cuál es el objetivo de las deducciones objetivas en nuestro ordenamiento jurídico tributario, y su consiguiente finalidad; al respecto, consideramos que el objetivo de las deducciones objetivas es introducir un régimen simplificado de determinación de la renta neta del trabajo, a fin de facilitar las labores de recaudación y

13 Cabe indicar que si bien el Test de Igualdad propuesto por el Tribunal Constitucional sugiere la aplicación consecutiva de cada uno de los exámenes, para efectos académicos del presente trabajo, desarrollaremos todos los exámenes, aun cuando alguno de ellos no haya sido superado por la medida analizada. 
fiscalización del Impuesto a la Renta de personas naturales que generan rentas del trabajo.

Establecido el objetivo y la finalidad del Estado con la medida empleada, corresponde identificar si cumple en primer término con el objetivo propuesto, esto es, introducir un régimen simplificado de determinación de la renta neta del trabajo; al respecto, tenemos que el implantar un sistema de deducciones objetivas simplifica definitivamente la labor fiscal del Estado, toda vez que le permite sustraer gran parte de su capacidad logística del aspecto determinativo de la base imponible del Impuesto a la Renta, y concentrarlo en aspectos formales y/o ligados al pago del referido tributo, pudiéndose añadir que la referida simplificación repercute incluso en la autodeterminación de los contribuyentes del Impuesto a la Renta generadores de rentas de cuarta y quinta categoría, siendo además que en el caso de las personas que perciben rentas de quinta categoría, el beneficio de la simplificación para la determinación de la renta neta alcanza inclusive a los empleadores, que por delegación de la Ley del Impuesto a la Renta, se han convertido en agentes de retención, encargados de determinar y recaudar a través de la retención de ingresos de sus trabajadores el impuesto definitivo que a cada uno le corresponda pagar.

De lo expuesto, tenemos que las deducciones objetivas cumplen con el objetivo propuesto por el legislador, por lo que resta determinar si dicho objetivo cumple con la finalidad descrita anteriormente.

En relación a la finalidad del Estado, consistente en otorgar mayor facilidad en su labor de recaudación y fiscalización del Impuesto a la Renta de personas naturales que generan rentas del trabajo, cabe indicar que la introducción de un régimen simplificado consistente en la aplicación de deducciones objetivas, termina por coadyuvar en gran medida la facultad de fiscalización del Estado, habida cuenta que su labor se remitirá en este extremo en líneas generales ${ }^{14}$ a tomar la renta bruta declarada por el contribuyente por sus rentas del trabajo, aplicar al importe resultante la deducción

$14 \quad$ Es importante precisar que la labor de fiscalización del Estado en el caso de las rentas del trabajo, tiene otras aristas, tales como la determinación de la renta bruta del contribuyente, la correcta aplicación de exoneraciones o inafectaciones contempladas en la Ley del Impuesto a la Renta o en leyes especiales, así como la objetividad en la determinación del impuesto mediante la escala progresiva acumulativa, siendo que a pesar que éstas otras aristas se encuentran simplificadas en declaraciones a través de programas telemáticos, resulta innegable la labor del Estado en dichos aspectos. 
objetiva correspondiente, y finalmente establecer en base a las alícuotas progresivas acumulativas el impuesto que en definitiva le corresponda pagar.

Asimismo, en el ámbito de la recaudación del Impuesto a la Renta por las rentas del trabajo, si bien el impulso que podría dar a dicha finalidad un régimen simplificado sustentado en deducciones objetivas, no resulta manifiesto, es innegable que tal medida por lo menos permite al Estado una recaudación más rápida y eficiente, lo que se traduce en el hecho que por ejemplo, según la Superintendencia Nacional de Aduanas y de Administración Tributaria (SUNAT, 2014) en la regularización del Impuesto a la Renta del ejercicio 2013 correspondiente a las rentas producidas por personas naturales, el 75.9\% del total de ingresos, proceden de las rentas del trabajo, verificándose además un incremento incesante de presentaciones de declaraciones por regularización del Impuesto a la Renta de personas naturales desde el año 2000 hasta el 2014 inclusive.

Finalmente, cabe cuestionarse en relación a la finalidad perseguida por el Estado, si ésta resulta legítima acorde con la Constitución; sobre este aspecto, entendemos que la finalidad es legítima solo si encuentra respaldo en una norma o principio de rango constitucional, lo que no sucede en el presente caso, toda vez que la facilitación en la recaudación y fiscalización del Impuesto a la Renta generado por las rentas del trabajo, no constituye en definitiva el objetivo de alguna norma o principio constitucional, por lo que podemos concluir que la finalidad perseguida por el Estado es ilegítima, y por tanto no pasible de ser asumida como tal.

\subsubsection{Examen de Necesidad}

Según lo expuesto en el Capítulo I del presente trabajo, el examen de necesidad se enfoca en establecer una comparación entre la medida empleada y otra medida hipotética que no afecta el principio de igualdad, o que afectándolo es menos gravosa.

En tal sentido, corresponde verificar si la medida empleada, constituida por las deducciones objetivas para la determinación de la renta neta del trabajo, era necesaria en relación a la finalidad que perseguía el Estado, esto es, la facilitación de la recaudación y fiscalización del Impuesto a la Renta por las rentas del trabajo ${ }^{15}$, en la

15 Cabe anotar que aun cuando en el Punto 3.2.1 del presente Capítulo, se ha establecido que la finalidad perseguida por el Estado es ilegítima, para efectos académicos, continuaremos con el análisis tomando en cuenta la misma finalidad. 
medida que no exista otra medida menos gravosa para el principio de igualdad que cumpla a su vez con la finalidad perseguida.

Al respecto, consideramos que si bien la aplicación de deducciones objetivas para la determinación de la renta neta del trabajo como es el caso de nuestra Ley del Impuesto a la Renta, facilita las labores de recaudación y fiscalización del Estado, debe tenerse en cuenta que la referida medida se encuentra vigente desde hace más de 20 años, lo que implica que la medida empleada por el Estado debe reflejar la finalidad por la cual se creó.

En relación a lo anotado en el párrafo anterior, (SUNAT, 2014) se evidencia un crecimiento incesante de la recaudación del Impuesto a la Renta proveniente de las rentas del trabajo, desde el año 2000 hasta el 2014, así como un masivo cumplimiento de obligaciones tributarias formales, tal como es la presentación de la declaración jurada correspondiente a la regularización del Impuesto a la Renta (rentas de cuarta categoría), lo que evidencia que las deducciones objetivas formuladas por el Estado cumplen con su finalidad de recaudación.

Ahora bien, en el ámbito de la fiscalización de personas naturales por sus rentas del trabajo, no hay una data precisa al respecto de la cual se pueda verificar el volumen de fiscalizaciones llevadas a cabo por el Estado durante los últimos años a personas generadoras de rentas del trabajo, no obstante, consideramos que la eficiencia de las deducciones objetivas se sustenta justamente en el hecho que la labor de fiscalización del Estado sea mínima, lo cual resulta coherente con la conclusión a la que arribamos anteriormente, acerca de la prolijidad del fisco en la recaudación del Impuesto a la Renta derivado de las rentas del trabajo, por lo que se puede considerar que en este ámbito las deducciones objetivas también cumplen con la finalidad planteada.

Una vez verificado el cumplimiento de las finalidades por las cuales fueron concebidas las deducciones objetivas para la determinación de la renta neta del trabajo, resulta necesario indagar acerca de una medida opcional que cumpla con facilitar al Estado su labor de recaudación y fiscalización, pero que además resulte menos gravosa a la luz del principio de igualdad.

En ese sentido, consideramos dos medidas para la determinación de la renta neta del trabajo; la primera son las "deducciones subjetivas", que consisten en un sistema de deducciones a través del cual las personas naturales pueden deducir todos los gastos en los que incurren respecto a sus necesidades básicas vitales y las de su familia, así como los gastos que incidan directamente en sus rendimientos laborales de manera ilimitada; 
y la segunda son las “deducciones mixtas”, caracterizadas por ser una combinación de las deducciones objetivas y las subjetivas, con preeminencia de esta última, es decir, en líneas generales se trata de un sistema de deducciones para la determinación de la renta neta del trabajo que admite deducciones subjetivas pero con límites objetivos basados en porcentajes de ingresos netos o unidades de referencia preestablecidas como la Unidad Impositiva Tributaria, por ejemplo.

Ahora toca analizar las dos propuestas, "deducciones subjetivas" $\mathrm{y}$ "deducciones objetivas", y establecer si las referidas medidas cumplen con las finalidades propuestas por el Estado y si éstas además resultan menos gravosas que las deducciones objetivas.

\subsubsection{Deducciones Subjetivas}

Tal como se ha indicado anteriormente, las deducciones subjetivas tienden a reflejar de la mejor forma posible los gastos en que incurren las personas generadoras de rentas del trabajo, otorgándole al mínimo no imponible un carácter personal, cuyos efectos no transgreden el principio de igualdad, sino que por el contrario resultan ideales para su finalidad, que es atender los gravámenes que impone el Estado con la verdadera capacidad contributiva de los contribuyentes.

Al respecto, considerando la Premisa Base desarrollada en el Punto 3.2 del presente Capítulo, tenemos que "A" podría deducir sus cargas familiares, gastos de educación, salud, vivienda y otros gastos propios de su actividad profesional como médico de manera irrestricta, lo cual redundaría en un menor Impuesto a la Renta a pagar al final del ejercicio gravable, a comparación de "B", que solo tiene gastos de salud y vivienda, habida cuenta que a pesar que "A" y "B" obtienen los mismos ingresos, la base imponible de cada uno difiere; efectivamente, en el ejemplo propuesto, al tener "A" una mayor cantidad de gastos que comprenden su mínimo no imponible, su base imponible será inferior a la de "B" que tendrá una menor porción de gastos correspondientes a su mínimo vital, lo que finalmente se reflejara en el mayor impuesto a pagar de éste último.

Ahora bien, en relación a las finalidades que debe perseguir la medida, tenemos que actualmente, aún con los adelantos de sistematización de los controles fiscales implementados por el Estado, resultaría difícil y engorroso para éste último realizar sus labores de recaudación y físcalización, así como para los mismos contribuyentes 
resultaría complicado elaborar sus determinaciones y pagos del Impuesto a la Renta por sus rentas del trabajo, por lo que consideramos que si bien las deducciones subjetivas cumplen con el respeto irrestricto al principio de igualdad, no ocurre lo mismo con las finalidades propuestas por el legislador referidas a la facilidad en la recaudación y fiscalización del Impuesto a la Renta por rentas del trabajo, con lo que debe desestimarse esta medida alternativa.

\subsubsection{Deducciones Mixtas}

La medida propuesta en sustitución de las deducciones objetivas, en términos generales, radica en permitir a los contribuyentes tener acceso a un sistema dual, es decir, un sistema en el que se les permita a los contribuyentes optar por practicar las deducciones subjetivas con límites cuantitativos preestablecidos, y otro sistema en el que puedan confiar sus deducciones a tasas porcentuales preestablecidas de sus ingresos brutos, las cuales deberán ser actualizadas año a año, en base a factores económicos que sean identificables ${ }^{16}$.

De lo expuesto, se tiene que la medida propuesta si bien no promueve el respeto irrestricto al principio de igualdad como si lo hacían las deducciones subjetivas, también consideramos que la afectación al referido principio es mínima en comparación con la que propugnan las deducciones objetivas, lo que nos permite concluir que la medida propuesta es menos gravosa para el principio de igualdad que la que actualmente se encuentra contenida en la Ley del Impuesto a la Renta.

Respecto a las finalidades de facilitación en la recaudación y fiscalización del Impuesto a la Renta desarrolladas por el legislador, se debe tener en cuenta en primer término que la labor de fiscalización de las personas naturales no se vería afectada por la complejidad de la determinación de la base imponible, habida cuenta que la única variación radicaría en que con la medida propuesta, los contribuyentes podrían deducir la generalidad de los gastos que componen su mínimo vital, siendo que dicha variación, se vería cubierta por la obligación de los contribuyentes de justificar dichos gastos con los comprobantes de pago de ley, los cuales son en la actualidad contrastables con los proveedores, teniendo en cuenta además que dichas deducciones tendrán un límite cuantitativo que evitara que la labor de fiscalización del Estado se haga compleja por el

En el punto 3.6 del presente capítulo desarrollaremos con mayor detalle los criterios que consideramos deben ser tomados en cuenta en nuestra propuesta de Deducciones Mixtas. 
tiempo empleado, debiendo tener en cuenta además que en dichos casos, los contribuyentes estarían obligados a practicar una declaración jurada anual.

En relación a la finalidad de facilitar la recaudación del Estado, resulta evidente que la implementación de un sistema como el propuesto, mantendría la funcionalidad de la recaudación, por cuanto se conservaría la obligación del empleador en los casos de rentas de quinta categoría, de retener el Impuesto a la Renta y pagarlo, para el caso en el cual el contribuyente opte por el sistema de deducciones tasadas, mientras que para los contribuyentes que manifiesten su voluntad de optar por el sistema de deducciones subjetivas con límites cuantitativos, se implementarían declaraciones juradas que serían presentadas directamente al Estado; de esta manera, se tiene que la practicabilidad de la que goza el Estado actualmente para recaudar el Impuesto a la Renta por rentas del trabajo, sería similar.

De lo expuesto, tenemos que la medida propuesta resultaría menos gravosa para el principio de igualdad, y además cumpliría satisfactoriamente con las finalidades del Estado de facilitación en la recaudación y fiscalización del Impuesto a la Renta por rentas del trabajo.

En tal sentido, podemos concluir que las deducciones objetivas contenidas en la Ley del Impuesto a la Renta para la determinación de la renta neta del trabajo, no cumplen con el examen de necesidad, debido a que según lo analizado anteriormente, se ha podido verificar que existe una medida alternativa ("deducciones mixtas") que resulta menos gravosa para el principio de igualdad y además cumple con las finalidades de facilitar la recaudación y fiscalización perseguidas por el Estado.

\subsubsection{Examen de Proporcionalidad y Razonabilidad}

Tal como se detalló en el Capítulo I del presente trabajo, el examen de proporcionalidad radica en una comparación entre el grado de optimización del fin constitucional perseguido con la medida empleada y la intensidad de la afectación del principio de igualdad.

Las deducciones objetivas para la determinación de la renta neta del trabajo, resultan atentatorias contra el principio de igualdad, siendo que si bien ello podría verse justificado por la finalidad constitucional perseguida por dicha medida, ello no ocurre en el presente caso, toda vez que la medida impuesta por el Estado, a través de las deducciones objetivas, no encierra ninguna finalidad constitucional relevante, sino 
únicamente abarca finalidades funcionales del Estado, tales como la facilitación en la recaudación y fiscalización del Impuesto a la Renta por las rentas del trabajo.

Asimismo, tenemos que la intensidad de la afectación de la medida empleada por el Estado respecto del principio de igualdad, es grave, toda vez que la referida medida restringe el derecho constitucional de la mayoría de contribuyentes a tributar en base a su capacidad contributiva, sacrificando de esta manera un principio constitucional en aras de la simplificación administrativa que implica la medida empleada para el Estado.

En ese sentido, se tiene que las deducciones objetivas a que se refiere la Ley del Impuesto a la Renta para la determinación de la renta neta del trabajo, no cumplen con el examen de razonabilidad y proporcionalidad, habida cuenta que la medida empleada no guarda relación proporcional entre la afectación al principio de igualdad y la optimización de la finalidad perseguida, máxime cuando dicha finalidad no resulta relevante en el ámbito constitucional.

\subsection{Análisis de las deducciones para la determinación de la renta neta del trabajo a través del principio de no confiscatoriedad}

Las deducciones objetivas establecidas por el legislador para la determinación de la renta neta del trabajo, no solo son pasibles de ser analizadas desde el principio de igualdad, sino que además pueden ser abordadas desde la perspectiva de la afectación económica al derecho de propiedad que implica el principio de no confiscatoriedad.

$\mathrm{Al}$ respecto, debemos tener en cuenta que:

Uno de los principios constitucionales a los cuales está sujeta la potestad tributaria del Estado es el de no confiscatoriedad de los tributos. Este principio informa y limita el ejercicio de la potestad tributaria estatal y, como tal, constituye un mecanismo de defensa de ciertos derechos constitucionales, empezando, desde luego, por el derecho de propiedad, ya que evita que la ley tributaria pueda afectar irrazonable y desproporcionadamente la esfera patrimonial de las personas. Asimismo, se encuentra directamente conectado con el derecho de igualdad en materia tributaria o, lo que es lo mismo, con el principio de capacidad contributiva, según el cual, el reparto de los tributos ha de realizarse de forma tal que se trate igual a los iguales y desigual a los desiguales, por lo que las cargas tributarias han de recaer, en principio, donde exista riqueza que pueda ser gravada, lo que evidentemente implica que se tenga en consideración la capacidad personal o patrimonial de los contribuyentes. 
$(\ldots)$

Ciertamente, el principio precitado es un parámetro de observancia que la Constitución impone a los órganos que ejercen la potestad tributaria al momento de fijar la base imponible y la tasa del impuesto. Éste supone la necesidad de que, al momento de establecerse o crearse un impuesto, con su correspondiente tasa, el órgano con capacidad para ejercer dicha potestad respete exigencias mínimas derivadas de los principios de razonabilidad y proporcionalidad.

Como tal, tiene la estructura propia de lo que se denomina un "concepto jurídico indeterminado". Es decir, su contenido constitucionalmente protegido no puede ser precisado en términos generales y abstractos, sino analizado y observado en cada caso, teniendo en consideración la clase de tributo y las circunstancias concretas de quienes estén obligados a sufragarlo. No obstante, teniendo en cuenta las funciones que cumple en nuestro Estado Democrático de Derecho, es posible afirmar, con carácter general, que se transgrede el principio de no confiscatoriedad de los tributos cada vez que un tributo excede el límite que razonablemente puede admitirse como justificado en un régimen en el que se ha garantizado constitucionalmente el derecho subjetivo a la propiedad y, además, ha considerado a ésta como institución, como uno de los componentes básicos y esenciales de nuestro modelo de Constitución económica. (Tribunal Constitucional, Expediente $\mathrm{N}^{\circ}$ 2727-2002-AA/TC, 2002)

Teniendo en cuenta lo expuesto, se tiene que la transgresión al principio de no confiscatoriedad puede verificarse no solo en relación a la tasa impositiva, sino también respecto a la base imponible del impuesto por ejemplo, toda vez que dicho elemento en la determinación del quantum del tributo resulta preponderante, y por consiguiente de especial relevancia al momento de la calificación de la medida como confiscatoria o no.

Efectivamente, si bien el Tribunal Constitucional ha afirmado con carácter general, que se transgrede el principio de no confiscatoriedad de los tributos cada vez que un tributo excede el límite que razonablemente puede admitirse como justificado en un régimen en el que se ha garantizado constitucionalmente el derecho subjetivo a la propiedad, ello no nos releva de un análisis específico caso por caso, dado que si bien el tributo y sus características son las mismas para todos los contribuyentes, las situaciones económicas y capacidad contributiva de cada uno de éstos difiere, lo que hace necesario un análisis personal.

En atención a lo señalado en el párrafo anterior, tomaremos la Premisa Base planteada al inicio del presente capítulo como punto de partida para relevar el resultado de nuestro análisis: 


\section{i) Análisis de la confiscatoriedad en " $\mathrm{A}$ "}

Los ingresos brutos de "A" por sus rentas del trabajo en el ejercicio 2014, ascienden a S/.150,000.00 anuales (S/.90,000.00 por rentas de cuarta categoría, y S/.60,000.00 por rentas de quinta categoría), y su mínimo vital, compuesto por cargas familiares, salud, educación, entre otros, asciende a S/.120,000.00 al año.

Ahora bien, de acuerdo con lo establecido en la Ley del Impuesto a la Renta, la base imponible afecta es el resultado de deducir de sus rentas de cuarta categoría el 20\%, y del resultado, más las rentas de quinta categoría, $7 \mathrm{UIT}^{17}$, lo que equivale a S/.105,400.00.

Del ejercicio propuesto, se evidencia que si bien la utilidad generada por " $A$ " equivale a la diferencia entre sus ingresos brutos y el mínimo vital, esto es, S/.30,000.00, de acuerdo con las deducciones objetivas establecidas actualmente en la Ley del Impuesto a la Renta, la base imponible equivale a $\mathrm{S} / .105,400.00$, lo que excede la capacidad contributiva de "A" de manera desproporcionada, pudiéndose concluir que la base imponible propuesta por la Ley del Impuesto a la Renta en el caso concreto, vulnera el principio de no confiscatoriedad.

\section{ii) Análisis de la confiscatoriedad en "B"}

Los ingresos brutos de "B" por sus rentas del trabajo en el ejercicio 2014, ascienden a S/.150,000.00 anuales (S/.90,000.00 por rentas de cuarta categoría, y S/.60,000.00 por rentas de quinta categoría), y su mínimo vital, compuesto por gastos de educación y salud, entre otros, ascienden a S/.40,000.00 al año.

De acuerdo con lo establecido en la Ley del Impuesto a la Renta, la base imponible afecta es el resultado de deducir de sus rentas de cuarta categoría el 20\%, y del resultado, más las rentas de quinta categoría, 7 UIT, lo que equivale a $\mathrm{S} / .105,400.00$.

Del ejercicio propuesto, se evidencia que la utilidad generada por "B" equivalente a la diferencia entre sus ingresos brutos y el mínimo vital, esto es, S/.110,000.00, es mayor a la que resulta de la aplicación de las 
deducciones objetivas establecidas actualmente en la Ley del Impuesto a la Renta (S/.105,400.00), lo que evidencia un efecto contrario al descrito en el caso de "A".

En relación con los casos propuestos, tenemos que con la aplicación de las deducciones objetivas descritas en la Ley del Impuesto a la Renta, si bien en el caso de "A" se obtuvo una base imponible superior a su verdadera capacidad contributiva, lo que determinó un efecto confiscatorio en el caso concreto; en el caso de "B", con las mismas deducciones objetivas, se obtuvo un resultado exactamente inverso, es decir, la base imponible determinada revelaba una menor capacidad contributiva de la que verdaderamente tenía "B".

Ello nos permite concluir que la aplicación de deducciones objetivas, esto es, la aplicación de deducciones sin discriminar a los contribuyentes en base a sus capacidades contributivas, termina por distorsionar la base imponible del Impuesto a la Renta y el sentido del mismo impuesto, que es justamente imponer un gravamen sobre las utilidades o rentas netas que los contribuyentes obtienen en un ejercicio determinado por su trabajo personal, deviniendo muchas veces dicha distorsión en una transgresión efectiva del principio de no confiscatoriedad.

\subsection{Análisis de las deducciones para la determinación de la renta neta del trabajo a través del principio de capacidad contributiva}

Como se ha expuesto en el Capítulo I del presente trabajo, el principio de capacidad contributiva es la aptitud que tienen los contribuyentes para soportar un determinado gravamen, es decir, es la capacidad de los contribuyentes para colaborar con el gasto público del Estado a través de gravámenes.

Ahora en el caso del Impuesto a la Renta, este gravamen es calculado sobre la capacidad contributiva de los contribuyentes, el cual viene a ser el resultado de deducir de los ingresos obtenidos en un ejercicio el mínimo no imponible y los gastos dirigidos a la generación de renta y mantenimiento de la fuente productora de la misma, al respecto, cabe cuestionarse para efectos del presente análisis, si las deducciones objetivas contempladas en la Ley del Impuesto a la Renta para la determinación de la renta neta del trabajo, permiten en todos los casos que el Impuesto a la Renta sea aplicado sobre la capacidad contributiva de las personas. 
En relación a la cuestión planteada, resulta claro que un sistema de deducciones objetivas como el actual, no siempre permite que el gravamen del Impuesto a la Renta repose sobre la capacidad contributiva de las personas naturales, en la medida que los gastos que componen el mínimo no imponible del contribuyente y los gastos en que éste pudiera haber incurrido durante el ejercicio para la obtención de renta gravada y el mantenimiento de la fuente, no siempre se encuentran subsumidos en las 7 UIT y en el $20 \%$ de la renta bruta que señala la Ley del Impuesto a la Renta.

En ese sentido, tenemos que en algunos casos el gravamen del Impuesto a la Renta afectará no solo la capacidad contributiva de las personas por sus rentas del trabajo, sino también su capacidad económica, lo que evidencia la transgresión en algunos casos del principio de capacidad contributiva; sin embargo, persiste la duda acerca de si mantener la puridad del principio de capacidad contributiva, es una finalidad posible, o si responde al idealismo del referido principio.

\subsection{EI principio de practicabilidad en las deducciones para la determinación de la renta neta del trabajo}

Teniendo en cuenta lo expuesto en el último párrafo del punto anterior, esto es, acerca de la posibilidad de aplicar el principio de capacidad contributiva de manera estricta o de forma relativizada, consideramos oportuno acudir al principio de practicabilidad, a efectos de dilucidar si las deducciones objetivas planteadas por la Ley del Impuesto a la Renta, responden a dicho principio o no.

De acuerdo con el principio de practicabilidad desarrollado en el primer capítulo del presente trabajo, solo resulta posible emplear las normas y principios tributarios, en la medida que su aplicación guarde correlación con la capacidad del Estado para llevar a cabo dicha labor, toda vez que de lo contrario la efectividad de cualquier norma o principio resultaría afectada, en resumen, lo que este principio busca es no imponer al Estado deberes que no van acorde con su capacidad para cumplirlos.

Ahora, cabe preguntarse si es posible identificar el principio de practicabilidad en las deducciones objetivas a que se refiere la Ley del Impuesto a la Renta. Por nuestra parte creemos que no, toda vez que no existe una exposición de motivos de la imposición de dicha medida que pudiera justificar que las deducciones objetivas, esto es, su formulación y cuantía, hubieran respondido a un razonamiento premunido de 
fundamentos técnicos económicos, a partir de los cuales pudiera evidenciarse la intencionalidad del legislador.

Sin perjuicio de lo expuesto, consideramos que la intención del legislador al introducir un sistema de deducciones objetivo para la determinación de la renta neta del trabajo tenía como trasfondo, tal como lo hemos expresado anteriormente, la simplificación para la recaudación y fiscalización del Impuesto a la Renta de personas naturales por sus rentas del trabajo, sin embargo, incluso asumiendo esa idea, tal planteamiento resulta discutible, por cuanto no basta introducir medidas, como las deducciones objetivas con un fin aparentemente justificado en funcionalidades administrativas, sino que resulta preponderante evaluar el grado de afectación que éstas medidas tienen sobre el principio de capacidad contributiva principalmente, y si dicha afectación importa a su vez y en igual o similar intensidad la efectividad de las finalidades propuestas, lo cual ya ha sido analizado anteriormente en el Punto 3.2 del presente capítulo, concluyéndose que la afectación de la medida no justifica la afectación al principio de igualdad, que para efectos tributarios bien podría considerarse como una afectación al principio de capacidad contributiva, toda vez que es posible practicar otras medidas menos gravosas para el referido principio y que conlleven las mismas finalidades de simplificación en la recaudación y fiscalización del Impuesto a la Renta.

\subsection{Alcances para la determinación de la renta neta del trabajo en el Perú}

Como consecuencia del análisis de las deducciones objetivas para la determinación de la renta neta del trabajo a la luz de los principios rectores de la tributación, en especial del principio de capacidad contributiva (igualdad tributaria), concluimos que en algunos casos el referido sistema de deducciones vulnera los citados principios tributarios, por lo que si bien, tal como hemos indicado anteriormente, no es objeto del presente trabajo elaborar fórmulas rígidas o elaboraciones formales para la determinación de la renta neta del trabajo, consideramos que resulta apropiado culminar este capítulo de la tesis sugiriendo algunos alcances y criterios en base al análisis realizado, las normas legales anteriores (Decreto Legislativo $\mathrm{N}^{\circ}$ 200) y la legislación comparada, entre otros instrumentos. 
Ahora bien, antes de elaborar los alcances y criterios para la determinación de la renta neta del trabajo, conviene esbozar un marco general acerca de la economía laboral en el Perú, a fin de dar practicabilidad a las propuestas que desarrollaremos más adelante.

\subsubsection{Situación económica laboral en el Perú}

Según Villamil (2014), sustentándose en data extraída de la OIT ${ }^{18} /$ FORLAC 2013 y del INEI $^{19}$ 2014, sostiene en relación al empleo en el Perú que: i) el sector informal genera el $19 \%$ del $\mathrm{PBI}^{20}$, ii) $74 \%$ de la $\mathrm{PEA}^{21}$ tiene un trabajo informal, y los asalariados informales en el sector informal son el 56\%, y iii) el ingreso promedio en los segmentos formales, más que duplica el ingreso en los segmentos informales, precisando que la brecha se amplía con la edad y la educación.

Atendiendo a los datos estadísticos aportados por Villamil, resulta necesario tener en claro algunos conceptos económicos para comprender mejor la magnitud de lo expuesto en el párrafo anterior; en ese sentido, Jaramillo y Sparrow (2014) indican que desde el 2002, la OIT utiliza el término "economía informal" para reemplazar el uso generalizado del término "sector informal", precisando que el concepto de economía informal incluye trabajadores especialmente vulnerables, los cuales son aquellos que no están protegidos por el marco regulatorio o que carecen de protección del empleo (p.28). Asimismo, Velazco (2011) conceptualiza el empleo informal como el número total de empleos informales, sean realizados en empresas del sector formal, empresas del sector informal u hogares, durante un período de referencia determinado (p.12).

Según la OIT, los componentes del empleo informal son: a) Trabajadores por cuenta propia y empleadores dueños de sus propias empresas del sector informal, la naturaleza informal del empleo es el resultado de las características de la empresa. b) Miembros de cooperativas de productores informales, es decir, cooperativas no constituidas formalmente como entidades jurídicas; la naturaleza informal del empleo es el resultado de las características de la cooperativa. c) Trabajadores por cuenta propia que producen bienes exclusivamente para uso final propio de su hogar (agricultura de subsistencia,

\footnotetext{
18 Organización Internacional del Trabajo.

19 Instituto Nacional de Estadística e Informática. 
etc.). d) Trabajadores familiares no remunerados, independientemente de si trabajan en empresas del sector formal o informal; no tienen contratos de trabajo escritos, y el empleo no está sujeto a la legislación laboral, seguridad social, convenios colectivos, etc. e) Asalariados que tienen empleos informales, empleados por empresas del sector formal o informal o por hogares que les emplean como trabajadores domésticos asalariados. (Velazco, 2011, pp. 12 y 13)

De lo expuesto, tenemos que la informalidad del empleo se evidencia en trabajadores que laboran para una empresa informal, trabajadores que laboran para una empresa formal pero que carecen de contrato y beneficios laborales según la legislación vigente, trabajadores por cuenta propia que producen bienes para su propio hogar, y asalariados que tienen empleos informales como trabajadores domésticos.

Estando a los datos estadísticos desarrollados y teniendo clara la referencia a empleo informal, queda pendiente la pregunta ¿cómo o por qué se produce la informalidad?, toda vez que a partir de ello podremos entender mejor la problemática y por consiguiente ensayar medidas más adecuadas desde el ámbito analizado en el presente trabajo.

Al respecto, existen diversos enfoques, por ejemplo:

El Programa Regional del Empleo para América Latina y el Caribe (PREALC) de la OIT, planteó que la heterogeneidad estructural que caracteriza a las economías de los países en desarrollo conducía a la segmentación del mercado de trabajo. Se reconoce la existencia dual de sistemas de producción y empleo en los países de la región; éstos se diferencian en función de los grados de organización y los niveles de capital, productividad y tecnología con que se desarrolla el proceso productivo. Esta dualidad se refuerza con la existencia de un exceso de mano de obra que el sector moderno de la economía no es capaz de absorber por sus niveles de desarrollo, y por lo tanto se ve en la necesidad de trabajar en actividades de subsistencia de bajos ingresos, capital y tecnología (OIT, 2006).

Para de Soto (1986), los costos y barreras a la formalidad de las empresas, así como los excesivos controles gubernamentales afectan al sector formal. Esta situación explica el surgimiento de actividades no reguladas por el Estado, consideradas un signo de capitalismo popular, que surgen como respuesta a la rigidez de los Estados "mercantilistas" que sobreviven otorgando el privilegio de participar legalmente en la economía de una pequeña élite. (como se citó en Velazco, 2011, p.11) 
En ese sentido, consideramos que la informalidad del empleo, es un cúmulo de factores encabezados por las trabas burocráticas y los altos costos de la formalidad a nivel laboral e impositivo, teniendo en cuenta además que regularmente los contribuyentes no ven reflejados los aportes realizados a través de los impuestos en su bienestar general, el cual debería traducirse en servicios básicos que el Estado se encuentra obligado a brindar, lo que los lleva a repensar su actuación en el ámbito de la economía formal.

Lo desarrollado anteriormente, nos ha dado una visión general de la problemática del empleo informal en el Perú, pero resulta de especial relevancia tener datos acerca de la motivación y tendencia de los emprendedores y trabajadores en el Perú para ser informal; en ese respecto, Villamil (2014), con base en un estudio elaborado en el año 2013 por la OIT, denominado "Características del emprendedor informal limeño. Demografía, percepciones y actitudes”, determinó que una decidida mayoría, identificó como un factor del entorno nacional que afecta su emprendimiento, los elevados impuestos, mientras que en un mucho menor número apuntaron que era la complejidad del sistema tributario, entre otros factores.

Lo señalado, nos permite concluir que la informalidad del empleo en el Perú, y la consiguiente disminución de la base tributaria, se ha agravado en la última década, a pesar del desarrollo económico que el país ha alcanzado, siendo que dicha informalidad se funda principalmente en los altos impuestos que tendrían que afrontar los ciudadanos de ser formales, por ello, consideramos que corresponde una reforma tributaria en diferentes niveles, no obstante, siendo nuestro tema de tesis las rentas del trabajo, nos remitiremos a ello, quizá no con una disminución en las tasas impositivas, lo cual necesitaría eventualmente un estudio económico detallado, pero si con el sinceramiento de la capacidad contributiva de los contribuyentes a través de un sistema de deducciones coherente con la realidad económica de cada contribuyente.

\subsubsection{Deducciones Mixtas; una aproximación a la capacidad contributiva de las personas naturales generadoras de rentas del trabajo}

Tal como hemos indicado en el punto 3.6.1. del presente capítulo, si bien uno de los mayores obstáculos para la formalidad laboral y económica en el Perú son los altos impuestos, es evidente que dicha problemática no se remite exclusivamente a tal factor, sino que existen otros factores que componen en igual o menor medida esa circunstancia, sin embargo, consideramos que es un paso importante para vencer la 
informalidad laboral, propiciar a través del sistema tributario incentivos que atraigan a los trabajadores a la formalidad, por lo que a nuestro criterio sería un buen comienzo sincerar la capacidad contributiva de las personas naturales por sus rentas del trabajo, teniendo en cuenta que hoy es la mayor y en algunos casos la única fuente de ingresos de las persona naturales en el Perú.

En ese sentido, hemos desarrollado un sistema híbrido de deducciones denominado "deducciones mixtas" para la determinación de la renta neta del trabajo, el cual consiste en líneas generales en un sistema de deducciones dual, en el que se le permite al contribuyente que genera rentas de cuarta y/o quinta categoría optar entre practicar deducciones subjetivas con límites cuantitativos preestablecidos, o aplicar tasas porcentuales preestablecidas sobre sus ingresos brutos, las cuales se actualizarán año a año en base a factores económicos fácilmente identificables ${ }^{22}$.

Antes de desarrollar el sistema de deducciones propuesto, conviene absolver algunas cuestiones: ¿qué gastos garantizan una vida digna en los términos del artículo $1^{\circ}$ de la Constitución Política del Perú?; ¿cuáles de esos gastos son cubiertos por el Estado, hoy?; y ¿en qué consisten dichos gastos?

En relación a la primera pregunta, ¿qué gastos garantizan una vida digna?, podemos acudir al Tribunal Constitucional para tener claro qué debemos entender en primer término como vida digna, al respecto, dicho colegiado ha establecido lo siguiente:

Conforme a la Constitución Política del Perú, la dignidad del ser humano no sólo representa el valor supremo que justifica la existencia del Estado y de los objetivos que este cumple, sino que se constituye como el fundamento esencial de todos los derechos que, con la calidad de fundamentales, habilita el ordenamiento. Desde el artículo $1^{\circ}$ queda manifiesta tal orientación al reconocerse que "La defensa de la persona humana y el respecto de su dignidad son el fin supremo de la sociedad y del Estado", y complementarse dicha línea de razonamiento con aquella otra establecida en el artículo $3^{\circ}$, que dispone que "La enumeración de los derechos establecidos (...) no excluye los demás que la Constitución garantiza, ni otros de naturaleza análoga que se fundan en la dignidad del hombre (...)" (como se cita en Sentencia del Tribunal Constitucional No 2273-2005-PHC/TC, 2005)

22 Cabe precisar que si bien algunos de los gastos que más adelante identificaremos en cada uno de los sistemas de deducciones propuesto (mínimo no imponible), no son exclusivos para la determinación de la renta neta del trabajo, consideramos que en la medida que las rentas derivadas del trabajo personal son las que generan en su mayoría la PEA en el Perú, abordaremos el tema en función a dichas rentas para efectos del presente trabajo. 
El Tribunal Constitucional ya ha señalado anteriormente que no hay posibilidad de materializar la libertad si su establecimiento y garantías formales no van acompañados de unas condiciones existenciales mínimas que hagan posible su ejercicio real (García Pelayo, Manuel. Las transformaciones del Estado contemporáneo. Madrid. Editorial Alianza. 1980, pág. 26), lo que supone la existencia de un conjunto de principios que instrumentalicen las instituciones políticas (Roberto Nesta Brero y más de 5,000 ciudadanos contra la Presidencia del Consejo de Ministros, STC N. ${ }^{\circ} 0008-2003-A I / T C$ ) y que sirvan de garantía para el goce de los denominados derechos económicos, sociales y culturales (como se cita en Sentencia del Tribunal Constitucional N ${ }^{\circ}$ 2016-2004AA/TC, 2004)

En orden con lo desarrollado por nuestro Tribunal Constitucional, consideramos que los gastos que favorecen la materialización de una vida digna, son aquéllos que nos permiten ponernos en condiciones de ejercer libremente nuestros derechos sociales, económicos y culturales; en ese sentido, podemos identificar a dos grupos de gastos, los que coadyuvan a mantener el bienestar y la integridad física y emocional del individuo, y en segundo término gastos que permitan desarrollarse dentro de la sociedad con armonía, esto es, gastos que eleven el nivel intelectual o de conocimientos del individuo, y que le faciliten llevar a cabo sus actividades laborales, con el objetivo de insertarse en la sociedad.

¿En qué consisten los gastos mencionados?, al respecto, hemos identificado a los gastos conforme a lo siguiente, dentro del primer grupo de gastos podemos incluir a los referidos a alimentación (alimentos y vestido), salud, vivienda, educación y sociales; mientras que dentro del segundo grupo, consideramos a los gastos de generación de rentas del trabajo.

Habiendo identificado los gastos que consideramos atienden de manera general el concepto de vida digna de la persona que exige la Constitución Política del Perú, corresponde responder ¿cuáles de esos gastos son cubiertos por el Estado, hoy?, toda vez que solo en la medida que dichos gastos no sean asumidos por el Estado, resultara razonable autorizar a los contribuyentes generadores de rentas del trabajo la deducción de los mismos; al respecto, sustentándonos en las cifras publicadas por el INEI en setiembre de 2015, a través de un estudio denominado "Perú Síntesis Estadística 
2015"23, en el que se destacan los porcentajes de participación de la población en educación, salud y vivienda, podemos identificar que dichos gastos son cubiertos por el Estado parcialmente y solo en algunos casos, mientras que los demás gastos difícilmente podrían colocarse en la categoría de parcialmente cubiertos por lo menos, habida cuenta que en esos casos los contribuyentes son los que de sus rentas cubren esa brecha; en ese sentido, podemos ensayar algunos lineamientos o criterios que permitan a través de las deducciones mixtas, adecuar la capacidad contributiva de las personas generadoras de rentas del trabajo a la realidad.

\subsubsection{Deducciones básicas}

El primer paso para la determinación de la renta neta del trabajo, consiste en aplicar deducciones básicas con límites preestablecidos, esto es, deducciones que abarquen los gastos esenciales que garanticen la vida digna de un individuo y la de su familia, de ser el caso, lo que en buena cuenta constituye el mínimo no imponible (concepto desarrollado en el Capítulo I del presente trabajo).

Al respecto, Herrera Molina (1998) señala que el principio de capacidad contributiva exige que el mínimo no imponible se ajuste a la realidad, pero no otorga una indicación precisa sobre su cuantía, por cuanto existen factores de hecho y de derecho que inciden en dicha cuantificación, como: i) coste de vida que varía no sólo a lo largo del tiempo, sino en las diversas localidades de un país; ii) el grado de bienestar alcanzado por la sociedad que incide en el nivel de vida que se considere "mínimo" para una existencia acorde a la dignidad humana; y iii) el nivel de prestaciones asistenciales que otorgue el propio Estado o instituciones benéficas. (p.121)

Es así que de lo expuesto y de los gastos identificados en el Punto 3.6.2 del presente capítulo, esto es, gastos de alimentación, salud, vivienda, educación y sociales, los cuales consideramos que en el caso del Perú componen el mínimo exento, podemos a continuación ensayar algunos criterios o lineamientos aplicables para la determinación de dichos gastos:

Según INEI, Estudio "Perú Sintesis Estadistica 2015”, Lima, setiembre 2015. Disponible en: https://www.inei.gob.pe/media/MenuRecursivo/publicaciones_digitales/Est/Lib1292/libro.pdf (Consulta realizada el 29 de enero de 2016.) 
- Aplicación de los gastos

Si bien el generador de rentas del trabajo es una persona natural que se encuentra dentro de la PEA, ésta generalmente pertenece a un grupo familiar, el cual en el caso del Perú, se encuentra conformado por cónyuge o conviviente, hijos y eventualmente otros dependientes; en ese sentido, a través de los gastos que componen el mínimo no imponible antes identificados, debe poder incluirse los gastos correspondientes al grupo familiar, en la medida que es el contribuyente quien soporta dicha carga familiar.

Ahora bien, es innegable el caso en el cual más de una persona genera rentas del trabajo en un mismo grupo familiar, por lo que deberá tenerse en cuenta ello al momento de la declaración jurada del Impuesto a la Renta correspondiente, de manera que no se permita deducir los mismos gastos en más de un contribuyente que compone el mismo grupo familiar; ello se puede lograr disponiendo que se consoliden los ingresos generados por los miembros de la familia y los gastos que componen el mínimo no imponible, en el contribuyente del grupo familiar que genera los mayores ingresos, de esta manera se puede evitar cualquier transgresión al respecto, pudiéndose incluso alentar una declaración informativa acerca del grupo familiar, lo que servirá de base para estimar los límites de las deducciones aplicables en cada caso.

\section{- Gastos de alimentación}

Es importante destacar que cuando nos referimos a gastos de alimentación, abarcamos a los gastos correspondientes a vestimenta y alimentación propiamente dicha; en ese sentido, consideramos que es posible calcular la deducción por este concepto en base al número y la edad de los integrantes del grupo familiar, lo cual sería consignado en la declaración informativa antes aludida, para sobre ello establecer un porcentaje predeterminado de la renta bruta del contribuyente a manera de límite de deducción por gastos de alimentación, tomando como punto de referencia la edad de cada uno de los integrantes del grupo familiar.

Nuestra propuesta se sustenta en que la alimentación más importante dentro del grupo familiar debe concentrarse en primer término en niños de 0 a 12 años y en adultos mayores de 65 a más, permitiendo de esta manera un 
porcentaje mayor de deducción de la renta bruta en ambos casos, y un menor porcentaje en los demás casos, con un límite fijo basado en la Remuneración Mínima Vital (RMV), por cuanto dicho indicador es el que finalmente refleja a su vez la canasta básica familiar.

\section{- $\underline{\text { Gastos de salud }}$}

Este es uno de los gastos más sensibles en el país, en la medida que el Estado, tal como se ha indicado anteriormente, no responde a la demanda de salud de manera satisfactoria, lo que sugiere que resulta más eficiente alentar a las personas a que contraten un seguro privado de salud en la medida de sus posibilidades, y que la atención del Estado en salud, se dirija a los sectores de la población que no puedan solventar sus gastos de salud.

En ese sentido, proponemos que las deducciones por salud, se calculen de dos formas alternativas, la primera en base a un promedio del costo de un seguro privado de salud en el país, con un límite porcentual de la renta bruta del contribuyente, y la segunda en base a la cantidad de individuos que componen el grupo familiar y a sus edades, estableciendo igualmente un límite porcentual en base a la renta bruta del contribuyente con un límite fijo en UIT; nótese que en este último caso se propone un límite fijo en UIT a diferencia de la primera forma en donde se propone solo un límite porcentual de la renta bruta, ello con la finalidad de incentivar la contratación de seguros privados de salud, que hagan más viable la atención en salud de las personas y de manera colateral hagan que el cálculo de la deducción en sí misma se simplifique, teniendo como externalidad positiva una disminución en la carga de atenciones de salud por parte del Estado.

\section{- $\quad$ Gastos de vivienda}

En este rubro podemos desarrollar los gastos correspondientes a los alquileres o a cuotas de créditos hipotecarios u otro instrumento financiero que tuviera por finalidad adquirir una vivienda, así como los gastos correspondientes a servicios básicos. 
Es importante destacar que lo que se pretende es permitir a los contribuyentes deducir parte de los gastos que implica acceder a una vivienda, con lo que descalificaríamos las adquisiciones de inmuebles para negocio, segunda vivienda o usos distintos a los de casa habitación, limitando además la posibilidad de la deducción a un número de UIT que equivalga al valor de una vivienda promedio, es decir, dirigir la deducción de gastos por vivienda a los contribuyentes que adquieren o alquilan un único inmueble que sea utilizado exclusivamente como casa habitación, y cuyo valor no exceda el límite razonable de una vivienda digna, siendo que en caso el valor de la vivienda o del alquiler de la misma excediera dicho límite, no se permita deducir el exceso.

Asimismo, en el caso de los servicios básicos, resulta importante tener en cuenta que hoy en día éstos han ampliado su rango de cobertura, por lo que actualmente tenemos los servicios de agua, desagüe, energía, gas, teléfono e incluso algunos países han empezado a considerar el internet como un servicio básico, no obstante, dada la realidad económica en el Perú comentada anteriormente, nos quedaremos con los cinco primeros servicios para identificarlos como básicos.

Habiendo identificado los servicios básicos, consideramos que la mayoría de éstos servicios, con excepción del gas, son perfectamente identificables y cuantificables, por lo que no existe mayor impedimento para el Estado en fiscalizar esta clase de gastos, a los cuales correspondería aplicarles un monto fijo calculado en UIT, tomando en cuenta el número de personas que conforman el grupo familiar y habitan la vivienda familiar, y los estándares de consumo de cada servicio básico según la composición del grupo familiar, de esta manera será posible que por ejemplo en un grupo familiar conformado por dos adultos y un niño, se pueda fijar en UIT un monto fijo a deducir por cada servicio básico.

\section{- Gastos de educación}

En este punto debemos considerar que si bien el plano educativo no se encuentra dirigido a un sector determinado de personas por su edad, se debe tener en cuenta que los gastos analizados deben ser abordados desde la perspectiva de 
proporcionar a las personas una educación básica que aliente su desarrollo y les permita tener una vida digna; en ese sentido, consideramos que los gastos de educación sólo deben estar dirigidos a aquellos dependientes cuya edad no sea superior a la mayoría de edad establecida en el Perú (18 años), salvo que desarrollen estudios técnicos o superiores con éxito, en cuyo caso se podría permitir la deducción hasta los 25 años de edad (tiempo aproximado para culminar una carrera técnica o universitaria); asimismo, podría admitirse la deducción de los gastos de la educación básica regular (secundaria completa) sin remitirse a la edad, pero sólo en esos casos.

Ahora bien, los gastos de educación antes mencionados, independientemente de los matices de cada caso (educación básica, técnica o superior), deberían tener un límite porcentual en base a la renta bruta del contribuyente, con un límite específico de UIT que justifique un gasto razonable en este rubro.

- $\quad$ Gastos sociales

En el presente caso hemos utilizado la denominación "gastos sociales" para englobar en dicho rubro los gastos que los grupos familiares llevan a cabo en recreación, lo cual si bien en primera instancia podría estimarse como un concepto que no resulta necesario para una vida digna, debemos tener en cuenta lo acotado por Herrera Molina en cuanto a la incidencia del grado de bienestar alcanzado por la sociedad en la dignidad humana.

Sin perjuicio de lo expuesto, consideramos que en este caso específico, es difícil someter al Estado a una tarea tan compleja como es la de estimar el grado de recreación de cada grupo familiar y cuantificarlo, por lo que en aplicación del principio de practicabilidad desarrollado a lo largo del presente trabajo, convendría identificar un límite porcentual general en base a la renta bruta obtenida en el ejercicio por cada contribuyente con un límite fijo de UIT, evitando de esta manera llegar a distorsionar la naturaleza del gasto social.

Para culminar con el desarrollo de los llamados gastos básicos, debemos destacar que los límites porcentuales propuestos en base a la renta bruta del contribuyente, deben necesariamente estar premunidos de estudios técnicos económicos para cada tipo de gastos, con cargo a ser actualizados de manera 
periódica, según los cambios en los factores que pudieran impactar en cada uno de los gastos básicos, siendo que similar criterio debe ser aplicado en los casos en los que se aplican como límites fijos la UIT o la RMV.

Asimismo, debe tenerse en cuenta que en todos los casos, los gastos deben estar debidamente sustentados a través de comprobantes de pago en los términos del Reglamento de Comprobantes de Pago, y éstos a su vez deben estar anotados en un registro electrónico de Egresos, debiendo presentar una declaración anual con la información consolidada de los ingresos y egresos del contribuyente o de los contribuyentes del grupo familiar, de ser el caso.

No obstante, en los casos en los que el contribuyente no desee o no pueda sustentar los gastos básicos efectuados a lo largo del ejercicio, debe tener la opción de aplicar una deducción objetiva fijada en base a la RMV, la cual deberá ser actualizada anualmente por el IPC, de manera que pueda contemplarse un mínimo de gastos básicos que permitan la vida digna del grupo familiar.

De esta forma se está tutelando el derecho de las personas a una vida digna a partir de su manifestación de capacidad contributiva, sin dejar de lado la posibilidad del Estado de mantener la recaudación y fiscalización dentro de sus parámetros.

\subsubsection{Deducciones para la determinación de la renta neta del trabajo dependiente}

Habiendo desarrollado los gastos que consideramos básicos para la vida digna de un contribuyente y/o grupo familiar, toca establecer las deducciones para la determinación de la renta neta del trabajo dependiente.

Tal como hemos indicado a lo largo del presente trabajo, las rentas del trabajo, no son generadas por una actividad laboral con características únicas, sino que tenemos dos clases de actividades laborales, la actividad generadora de renta del trabajo dependiente (renta de quinta categoría), y la actividad generadora de renta del trabajo independiente (renta de cuarta categoría), por lo que toca desarrollar las deducciones aplicables en cada caso de manera separada, iniciando por la correspondiente a las rentas de quinta categoría. 
Al respecto, Costa Gonzales (2004) señala que la renta neta en el caso del trabajo dependiente debería equivaler al total de la renta bruta, en la medida que no existiría un gasto adicional al de la utilización del esfuerzo practicado por la persona física, salvo casos en los cuales la particularidad del trabajo realizado, obligue al trabajador a utilizar ropa especial, o a incurrir en costos altos por alimentación o transporte, precisando el autor que en aquellos casos generalmente dichos costos o gastos son asumidos por el empleador y son integrados a la remuneración. (p.90)

No obstante lo acotado por Costa Gonzales, diferimos en parte de la opinión vertida por el autor, habida cuenta que si bien es cierto, la inversión identificable en el caso de las rentas del trabajo dependiente se remite a la dedicación personal o al tiempo empleado en la labor desarrollada, resulta innegable que sobre todo en los casos de profesionales o técnicos, los estudios que incrementen las capacidades de éstos, constituyen una inversión en sí mismos como capital humano, por lo que se debe admitir la deducción de dichos estudios siempre que la inversión proceda únicamente de los ingresos del contribuyente, y no se haya utilizado dicha deducción por la entidad, empresa o persona generadora de renta de tercera categoría para la cual labora.

En relación al límite de la deducción propuesta, consideramos que debe establecerse en base a UIT, en atención a las características del grado educativo o de especialidad del estudio que el contribuyente realiza, toda vez que la inversión oscila generalmente en relación a la especialidad del estudio realizado. Al igual que en el caso de los gastos básicos, éstos gastos deberán estar soportados por comprobantes de pago y registrados en un registro electrónico de egresos, y se consignaran en la misma declaración que contienen los gastos básicos, siendo que en caso no se justifique éstos gastos, no procederá deducción alguna.

Finalmente debemos acotar que ésta deducción no se encuentra contemplada dentro de los gastos básicos de educación antes desarrollados, por cuanto según se anotó en dicho acápite, la educación básica, técnica o superior tiene claros limitantes de edad o nivel educativo, mientras que en el presente caso, lo que se pretende es admitir la deducción de estudios de especialidad técnica o superior adicionales a los obtenidos anteriormente, que coadyuven a la generación de renta gravada. 


\subsubsection{Deducciones para la determinación de la renta neta del trabajo independiente}

En relación a las deducciones para la determinación de la renta neta del trabajo independiente, Costa Gonzales (2004) señala que a diferencia de las rentas del trabajo dependiente, en este caso el contribuyente incurre en ciertos riesgos para obtener el éxito requerido, debiendo incluso incurrir en gastos necesarios para obtener la renta. Destacando además que si bien en ciertos casos se puede entender que se aplique capital, éste aplica únicamente en los términos que se considere imprescindible para posibilitar la utilización de aquel. (p.91)

Es así que el mismo autor añade que para la determinación de la renta neta del trabajo independiente se deberá admitir la deducción de determinados gastos que son necesarios para la obtención de aquella, tales como la remuneración de terceros, del capital empleado, así como la depreciación en el caso de uso de bienes de su propiedad. (p.92)

Coincidimos con las conclusiones de Costa Gonzales acerca de la determinación de la renta neta del trabajo independiente, toda vez que resulta innegable que las rentas obtenidas por el trabajo independiente conllevan una cierta dosis de riesgo y de capital propio del contribuyente, que se pueden traducir en rentas no periódicas ni iguales, e incluso pérdidas; a diferencia de las rentas del trabajo dependiente, en donde las rentas tienen un carácter periódico e invariable por naturaleza, sin importar el resultado alcanzado.

En ese sentido, consideramos apropiado como lineamientos a tener en cuenta para la determinación de la renta neta del trabajo independiente, admitir las deducciones de alquileres, cuotas de créditos hipotecarios, material que permita al contribuyente desarrollar su arte, profesión u oficio, remuneraciones de personal de apoyo y servicios generales, bajo determinados parámetros que permitan esclarecer la capacidad contributiva del contribuyente sin afectar la recaudación o fiscalización del Estado.

De acuerdo con lo anotado, consideramos que en el caso de las deducciones de alquileres y cuotas de créditos hipotecarios, se puede establecer un porcentaje de la renta bruta con un límite basado en UIT, teniendo en cuenta como parámetro que éstos alquileres y cuotas de créditos hipotecarios correspondan a un inmueble que sea utilizado únicamente para los fines de generación de renta del trabajo independiente, toda vez que de otra forma, se podría favorecer sin intención una doble deducción por 
este concepto, como gasto básico de vivienda y gasto por rentas del trabajo independiente.

De igual forma, el personal de apoyo, debe ser considerado como el que coadyuva al contribuyente a generar rentas del trabajo independiente, lo que permite excluir a las personas que lleven a cabo labores principales o cuya realización implique o abarque las funciones del contribuyente, en la medida que la intervención de éste último sea complementaria o sin relevancia para el servicio finalmente obtenido por el cliente. En este caso, consideramos que la aplicación de un porcentaje de la renta bruta con un límite basado en UIT puede reflejar de muy buena manera el impacto del personal de apoyo en la generación de renta del trabajo independiente.

De otra parte, la deducción de servicios generales, esto es, agua, desagüe, energía, teléfono e internet, constituyen elementos importantes para la generación de renta del trabajo independiente, por lo que deben ser admitidos en la medida que se encuentren referidos únicamente a un inmueble utilizado solo para la generación de renta de cuarta categoría, sin embargo, resulta importante contemplar la posibilidad de admitir la deducción de éstos gastos cuando el contribuyente lleva a cabo el trabajo en su vivienda, en cuyo caso deberá permitirse un porcentaje de la renta bruta adicional al admitido para las deducciones básicas por estos conceptos.

Al igual que en los casos anteriores la deducción debe estimarse con un límite porcentual de la renta bruta y un límite fijo en UIT, debiendo destacarse que en este caso, a diferencia de los servicios básicos, los servicios generales, deben calcularse teniendo en cuenta la finalidad de generación de renta que subyace en estos gastos.

Finalmente, dentro de la deducción de "materiales" que indicamos debe permitirse para la determinación de la renta neta del trabajo, hemos agrupado elementos que consideramos relevantes para la mejora del contribuyente como capital humano, tales como estudios técnicos, superiores o cursos que incrementen sus conocimientos en el rubro en el que se desempeña, además de útiles de oficina, materia prima, entre otros que permitan al contribuyente desarrollar su labor, así como la de su personal de apoyo.

En el caso de los estudios técnicos o superiores o cursos, resulta importante destacar que en caso el contribuyente perciba rentas de quinta categoría adicionalmente, solo tendrá derecho a deducir una vez los gastos consistentes en estudios, a su elección, es decir, en la determinación de la renta neta de quinta o cuarta categoría. Siendo que en caso de deducirse como parte de las rentas de cuarta categoría, la deducción admitida como porcentaje de la renta bruta con un límite fijo de UIT, debe ser mayor a la 
permitida para la determinación de la renta neta del trabajo dependiente, dada la complejidad para la obtención de éstas rentas. Similar es el caso de los útiles de escritorio y materias primas que coadyuven a la generación de renta del trabajo independiente, en donde se debe fijar un límite porcentual de la renta bruta para la deducción con un límite fijo en UIT, que verdaderamente refleje la importancia de éste gasto en la labor que lleva a cabo el contribuyente.

Finalmente, resulta adecuado precisar que no hemos tomado la depreciación como un gasto para la determinación de la renta neta del trabajo independiente, contrariamente a lo acotado por Costa Gonzales, habida cuenta que consideramos que introducir un sistema de depreciación que sea practicable por personas naturales, resultaría complejo e incluso contraproducente para los fines de la simplificación administrativa, lo cual no excluye la idea de incorporar más adelante este elemento, pero solo en la medida que la formalidad y conocimiento de los contribuyentes lo permita.

Las pérdidas arrastrables para la determinación de la renta neta del trabajo independiente, merecen una mención especial, y es que resulta plenamente justificado admitir las pérdidas generadas en ejercicios anteriores, toda vez que de otra manera, se estaría soslayando el principio de continuidad de la labor que lleva a cabo el contribuyente; en ese sentido, es apropiado que se admita el arrastre de pérdidas hasta por cuatro ejercicios consecutivos.

Como regla general, en todos los casos, los gastos deben estar debidamente sustentados a través de comprobantes de pago en los términos del Reglamento de Comprobantes de Pago, y éstos a su vez deben estar anotados en los respectivos registros y libros electrónicos, debiendo presentar una declaración anual con la información consolidada de los ingresos y egresos del contribuyente.

En los casos en los que el contribuyente no desee o no pueda sustentar los gastos para la determinación de la renta neta del trabajo independiente, debe tener la opción de aplicar una deducción objetiva fijada en base a la UIT, la cual deberá ser actualizada anualmente en base a factores económicos, de manera que pueda contemplarse un mínimo de gastos que permitan la generación de renta gravada.

Es importante, precisar que tanto en el caso de la determinación de los gastos básicos, rentas del trabajo dependiente y rentas del trabajo independiente, y sus respectivos gastos, y pérdidas, todas éstas deben estar dispuestas en una sola 
declaración jurada anual, toda vez que resultaría una complejidad innecesaria obligar a los contribuyentes a presentar una declaración en cada caso.

Después de haber desarrollado nuestra propuesta de criterios y lineamientos a tener en cuenta para la determinación de la renta neta del trabajo, debemos insistir en que lo expuesto no constituye una propuesta legislativa ni fórmulas o parámetros rígidos, sino lineamientos y criterios sustanciales que permitirán desarrollar con mayor acierto un sistema de deducciones para la determinación de la renta neta del trabajo, que se encuentre acorde con los principios rectores de la tributación, así como con las facultades del Estado para mantener su capacidad de recaudación y fiscalización, logrando inclusive como una externalidad positiva, la posibilidad de incrementar la base de contribuyentes y la consiguiente formalidad de la economía, en la medida que lo expuesto se acompañe con otras disposiciones que propicien ello. 


\section{CONCLUSIONES}

- Del análisis efectuado a lo largo del presente trabajo, tenemos como conclusión principal, que las personas que generan rentas del trabajo, cuyo mínimo no imponible y gastos asociados con la generación de renta gravada y mantenimiento de la fuente no son subsumidos por las deducciones objetivas planteadas por la Ley del Impuesto a la Renta, estaremos ante una situación de transgresión del principio de capacidad contributiva.

- Asimismo, tenemos que la relación entre los principios de igualdad, no confiscatoriedad y capacidad contributiva es directa, en la medida que como se ha visto en los análisis efectuados respecto de cada uno de estos principios, la transgresión de uno de ellos, deriva generalmente en la afectación del otro.

- En relación a lo expuesto, tenemos que en el análisis efectuado respecto del principio de igualdad, hallamos que la aplicación de deducciones objetivas a personas cuya capacidad contributiva era disímil, contravenía dicho principio en la medida que el principio de igualdad, no solo equivale a un mandato de prohibición de discriminación, sino también a un mandato de discriminación positiva cuando los sujetos o situaciones jurídicas a los cuales es aplicada una medida difieren en su condición o contenido.

- Tal como se plantea en el punto anterior, se estableció a partir de un análisis del cumplimiento de cada uno de los elementos que debe observar una medida como la planteada por la Ley del Impuesto a la Renta (deducciones objetivas), algunas conclusiones importantes. Por ejemplo, en relación al principio de igualdad, se realizaron tres subanálisis, determinándose en relación al examen de idoneidad, que la medida empleada por el Estado, si bien responde al objetivo, y éste último a su vez a la finalidad perseguida, tal finalidad resulta ilegítima, al no encontrar respaldo en norma o principio constitucional alguno. De igual manera, se pudo verificar a través del examen de necesidad, que la medida utilizada por el legislador, si bien cumplía con la finalidad propuesta, resultaba mucho más gravosa en relación a la afectación al principio de igualdad, que las deducciones mixtas planteadas en este trabajo como medida alternativa que adicionalmente cumplía satisfactoriamente con la finalidad de facilitar la recaudación y fiscalización del Impuesto a la Renta por las rentas del trabajo. Finalmente, se 
estableció mediante el examen de proporcionalidad y razonabilidad, que el grado de afectación del principio de igualdad con la medida empleada no guardaba relación proporcional ni índices de razonabilidad con la optimización de la finalidad perseguida, sobre todo cuando dicha finalidad no era constitucionalmente relevante.

- El principio de no confiscatoriedad encuentra su sustento en la capacidad contributiva de las personas, lo cual se evidenció en el presente trabajo cuando analizamos las deducciones objetivas y su impacto negativo en algunos casos, específicamente cuando éstas no abarcaban buena parte del "mínimo no imponible" y/o de los gastos para la generación de renta gravada o mantenimiento de la fuente, permitiendo que el gravamen repose sobre la capacidad económica del contribuyente y no sobre su capacidad contributiva.

- Es importante tener en cuenta que, las deducciones objetivas no son per se medidas impropias para la determinación de la renta neta del trabajo, toda vez que pueden ser actuadas en combinación con medidas que permitan una mejor adecuación a las situaciones económicas personales de cada contribuyente, por ejemplo, aplicando deducciones subjetivas con límites cuantitativos, o asignando una deducción subjetiva a una situación particular, lo cual es distinto a aplicar un sistema de deducciones ciego como el actual, que no permite cumplir con la finalidad del Impuesto a la Renta, que es gravar directamente la capacidad contributiva de las personas naturales por sus rentas del trabajo, en este caso.

- De otro lado, consideramos que no obstante el fin ideal que plantea el principio de capacidad contributiva, no debe dejarse de lado el principio de practicabilidad abordado durante el presente trabajo, en base al cual resulta posible mejorar el sistema actual, permitiendo la introducción de deducciones subjetivas con parámetros cuantitativos que tengan un contenido económico que justifique dichos parámetros, toda vez que si bien tales medidas no reflejan de manera fiel el contenido del principio de capacidad contributiva, constituyen medidas mucho menos gravosas que las actuales.

- De igual forma resulta importante resaltar que la posibilidad de implantar las deducciones subjetivas relativizadas, conforme se ha indicado en el párrafo anterior, no es una circunstancia que pudiera afectar las finalidades de recaudación y fiscalización del Estado, en base a las cuales se erigieron las deducciones objetivas en la Ley del Impuesto a la Renta, habida cuenta que hoy la 
capacidad logística del órgano de administración tributaria del Estado (SUNAT) supera largamente la existente hace 20 años.

Efectivamente, la generalización del uso de herramientas tecnológicas con relación a comprobantes de pago, registros contables, declaraciones juradas determinativas e informativas, entre otras medidas, impuestas originalmente a los proveedores de bienes y servicios, pueden ser utilizadas como base informativa que permita corroborar las deducciones declaradas por cada contribuyente generador de rentas del trabajo, no afectándose de esta manera las capacidades del Estado para recaudar y fiscalizar, sobre todo cuando la medida sugerida, a nuestro criterio, debería ir acompañada de una opción que permita al contribuyente efectuar la determinación de la base imponible de sus rentas del trabajo en base a deducciones objetivas que verdaderamente se asemejen a la situación económica de los contribuyentes.

De otro lado, no queríamos dejar pasar la oportunidad de hacer referencia a la modificación de la escala acumulativa progresiva para la determinación del Impuesto a la Renta de personas naturales, a pesar que ello no afecta el desarrollo ni las conclusiones del presente trabajo, por cuanto consideramos que aun así existe una conexión con el tema en desarrollo.

Al respecto, consideramos que la introducción de estos nuevos tramos solo implica un remedio superficial que se traduce en un menor pago de impuestos por parte de contribuyentes con ingresos bajos o medios, toda vez que la afectación a los principios tributarios de igualdad, no confiscatoriedad y capacidad contributiva antes mencionados, persiste al no existir elementos eficaces que permitan hacer una discriminación positiva en favor de los contribuyentes por su capacidad contributiva. En resumen, la modificación introducida por la Ley $\mathrm{N}^{\circ}$ 30296 al artículo $53^{\circ}$ de la Ley del Impuesto a la Renta, tiene un efecto inmediato que se percibirá en el ejercicio 2015, que es que las personas naturales con ingresos inferiores tributen menos, sin embargo, la base imponible sobre la cual se aplicaran estas nuevas alícuotas será la misma para todos, es decir, la base imponible correspondiente a dos personas que tienen iguales ingresos por sus rentas del trabajo, será la misma, aun cuando por ejemplo una de ellas tenga carga familiar y la otra no, lo que evidencia que la transgresión al principio de capacidad contributiva persistirá. 
- Finalmente, debemos señalar que la formulación de un sistema de deducciones subjetivas con parámetros cuantitativos, no solo beneficiara el derecho de los contribuyentes a tributar por sus rentas del trabajo de acuerdo con su capacidad contributiva, sino que además puede originar una externalidad positiva, como es el incremento de la base de contribuyentes.

Efectivamente, en la medida que los contribuyentes por rentas del trabajo deban contar con los comprobantes de pago que sustenten sus gastos e inversiones para obtener una mayor deducción, obligaran de manera indirecta a sus proveedores a formalizarse y por ende a ampliar la base tributaria, finalidad que constituye el ideal de un sistema tributario. 


\section{REFERENCIAS}

AAV. Landa Arroyo, C. (2006). Jurisprudencia y doctrina constitucional tributaria. Lima, Perú: Gaceta Jurídica - Centro de Estudios Constitucionales.

Álvarez Conde, E. (2003). Curso de derecho constitucional (4 ${ }^{a}$. ed.). Vol. I. Madrid, España: Tecnos.

Arbaiza Fermini, Lydia (2009). Economía informal y capital humano en el Perú. Lima, Perú: Universidad ESAN.

Bravo Cucci, J. (2013). Derecho Tributario Reflexiones. Lima, Perú: Jurista Editores E.I.R.L.

Calvo Ortega, R. (2004). Curso de derecho financiero. Tomo I. Derecho Tributario. Parte General. Navarra, España: Civitas Ediciones.

Calvo Ortega, R. (2008). Curso de derecho financiero. Navarra, España: Editorial Arazandi.

Costa Gonzales, C. (2004). Impuesto a la Renta Personal, Global y Progresivo. Montevideo, Uruguay: Fundación de Cultura Universitaria.

Danós, J. (2006). El principio constitucional de no confiscatoriedad. En Temas de Derecho Tributario y de Derecho Público. Libro Homenaje a Armando Zolezzi. (p. 141). Lima, Perú: Palestra Editores.

Ferreiro Lapatza, J. (2006). Curso de derecho financiero español. Madrid, España: Marcial Pons.

García Belsunce, H. (1982). Temas de derecho tributario. Buenos Aires, Argentina: Abeledo - Perrot.

Hernández Berenguel, L. (2005). Principio de legalidad y principio de no confiscatoriedad. En La Constitución Comentada. Análisis artículo por artículo. Tomo I. (p.969). Lima, Perú: Gaceta Jurídica.

Herrera Molina, P.M. (1998). Capacidad económica y sistema fiscal. Análisis del Ordenamiento Español a la luz del Derecho Alemán. Madrid, España: Marcial Pons.

Iglesias Ferrer, C. (2000). Derecho Tributario Dogmática General de la Tributación (1 ${ }^{a}$ ed.). Lima, Perú: Gaceta Jurídica. 
Jaramillo Baanante, Miguel, y Sparrow Alcázar, Bárbara (2014). Crecimiento y segmentación del empleo en el Perú. Lima, Perú: GRADE.

Martín Queralt, J. (2008). Curso de derecho financiero y tributario. Madrid, España: Editorial Tecnos.

Moschetti, F. (2001). El principio de capacidad contributiva. En Amatucci. A. (Director). Tratado de Derecho Tributario. Tomo I. (p.264). Bogotá, Colombia: Editorial Temis.

Pérez Royo, F. (2008). Derecho financiero y tributario. Parte General. Navarra, España: Thomson Civitas.

Rodríguez Losada, S. (2011). El Principio de Practicabilidad en Materia Tributaria. En Estudios de Derecho Constitucional y Tributario. (p.439). Lima, Perú: Fondo Editorial de la Universidad de San Martín de Porres.

Spisso, R. (2002). Derecho Constitucional Tributario. Buenos Aires, Argentina: Editorial Desalma.

Superintendencia Nacional de Aduanas y de Administración Tributaria - SUNAT (2014). Nota de Prensa $N^{\circ}$ 107-2014. Lima, Gerencia de Comunicaciones.

Tribunal Constitucional (2004). Sentencia $N^{\circ}$ 0033-2004-AI/TC de 28 de setiembre de 2004.

Tribunal Constitucional (2005). Sentencia $N^{\circ}$ 00045-2004-AI de 29 de octubre de 2005.

Tribunal Constitucional Español (1989). Sentencia $N^{\circ} 45 / 1989$ de 20 de febrero de 1989.

Tribunal Constitucional Español (1990). Sentencia $N^{\circ}$ 76/1990 de 26 de abril de 1990.

Tribunal Constitucional Español (2004). Sentencia $N^{\circ}$ 255/2004 de 29 de noviembre de 2004.

Uckmar, V. (2002). Principios Comunes del Derecho Constitucional Tributario. Bogotá, Colombia: Editorial Temis.

Velazco, Tatiana (2011). Empleo informal y políticas de protección social en el Perú. Retos y oportunidades para el nuevo gobierno. Lima, Perú: Consorcio de Investigación Económica y Social. 


\section{BIBLIOGRAFÍA}

AAVV. (1999). Derecho tributario, consideraciones económicas y jurídicas. Parte general. Tomo I. Buenos Aires: Editorial De Palma.

Medrano Cornejo, Humberto. (1994). "La reforma del Impuesto a la Renta de los profesionales. Revista del Foro". Colegio de Abogados de Lima. Vol. $N^{\circ} 1$. Lima.

Muñoz Blas, Carla Mercedes. (2010). "La capacidad contributiva como límite a la tributación de actos ilícitos: Referencia especial a los incrementos patrimoniales no justificados". Tesis para optar el título de master en tributación y política fiscal. Lima. Universidad de Lima.

Patton García, Gemma. (2013). La aplicación del Principio de Igualdad tributaria. Lima: INDESTA-SUNAT.

Paulo de Barros, Carvalho (Director). (2003). Tratado de Derecho Tributario. Lima. Palestra Editores.

Paulo de Barros, Carvalho. (2007). Curso de derecho tributario. Madrid: Marcial Pons.

Pérez Royo, Fernando et al. (2011). Curso de derecho tributario. Parte especial. Madrid: Editorial Tecnos.

Yacolca Estares, Daniel et al. (2010). Introducción al derecho financiero y tributario. Lima: Jurista Editores - Academia Internacional de Derecho Tributario. 


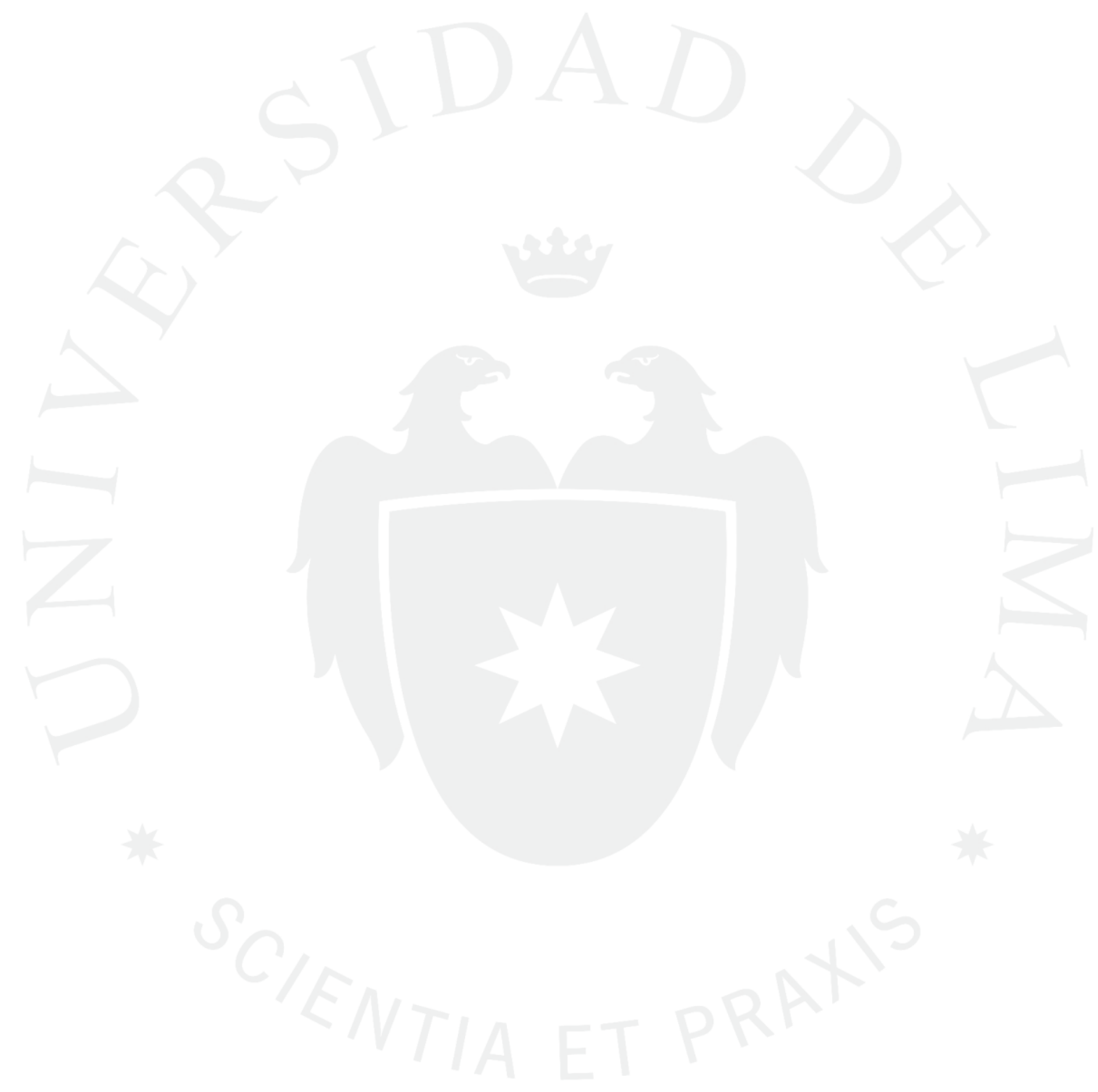

